\title{
A possible Neolithic settlement at Kinbeachie, Black Isle, Highland
}

\author{
G J Barclay*, S P Carter**, M M Dalland**, M Hastie**, \\ T G Holden**, A MacSween ${ }^{\ddagger} \&$ C R Wickham-Jones ${ }^{\S}$
}

\begin{abstract}
Monitoring by the farmer of a group of arable fields at Kinbeachie in the Black Isle, $20 \mathrm{~km}$ north of Inverness, led to an archaeological evaluation and the discovery and excavation of a site of Neolithic date. The site comprised a scatter of plough-truncated pits or post-holes contained within an area 30 by $30 \mathrm{~m}$ in extent. Only one structure was identified, a rectangular arrangement of post-holes which is interpreted as a timber building. Small assemblages of pottery, worked stone and carbonized crop plants were recovered and the site is interpreted as a relatively short-lived agricultural settlement. Radiocarbon dating suggests that the site was occupied at some time between 3500 and $2920 \mathrm{cal}$ BC. Wider issues discussed in the light of these results include the dating of Scottish Late Neolithic Impressed Ware and its relationship to other styles of pottery, the use of flint in Neolithic Scotland and the nature of settlement in the Neolithic.
\end{abstract}

\section{INTRODUCTION}

Kinbeachie Farm is located on the north side of the Black Isle in the agriculturally productive lowlands of eastern Ross \& Cromarty (the historical county), $20 \mathrm{~km}$ north of Inverness (NGR: NH 626 625). The farm fields of Kinbeachie, which are managed in a five-year arable rotation, extend for over a kilometre in a single rectangular block along the crest of a $120 \mathrm{~m}$ high sandstone ridge which overlooks the Cromarty Firth (illus 1). Persistent archaeological monitoring of these fields by the farmer of Kinbeachie, Mr Andrew Fraser, ultimately led to the identification and excavation of the site reported here.

The discovery and excavation of what may be a Neolithic settlement site, in this case dating from the period 3500-2920 cal $\mathrm{BC}$, is still a rare event in most of Britain. In this paper we present the results of the excavation and then discuss, at greater length, a number of broader topics in the archaeology of the Neolithic directly linked to the new findings.

The finds from all phases of the fieldwork are deposited in Inverness Museum \& Art Gallery. The site archive is deposited in the National Monuments Record of Scotland.

\footnotetext{
* Department of Environmental Science, University of Stirling, Stirling FK9 4LA

** Headland Archaeology Ltd, 13 Jane St, Edinburgh EH6 5HE

* Historic Scotland, Longmore House, Salisbury Place, Edinburgh EH9 1SH

$\S 21$ Dudley Gardens, Edinburgh EH6 4PU
} 


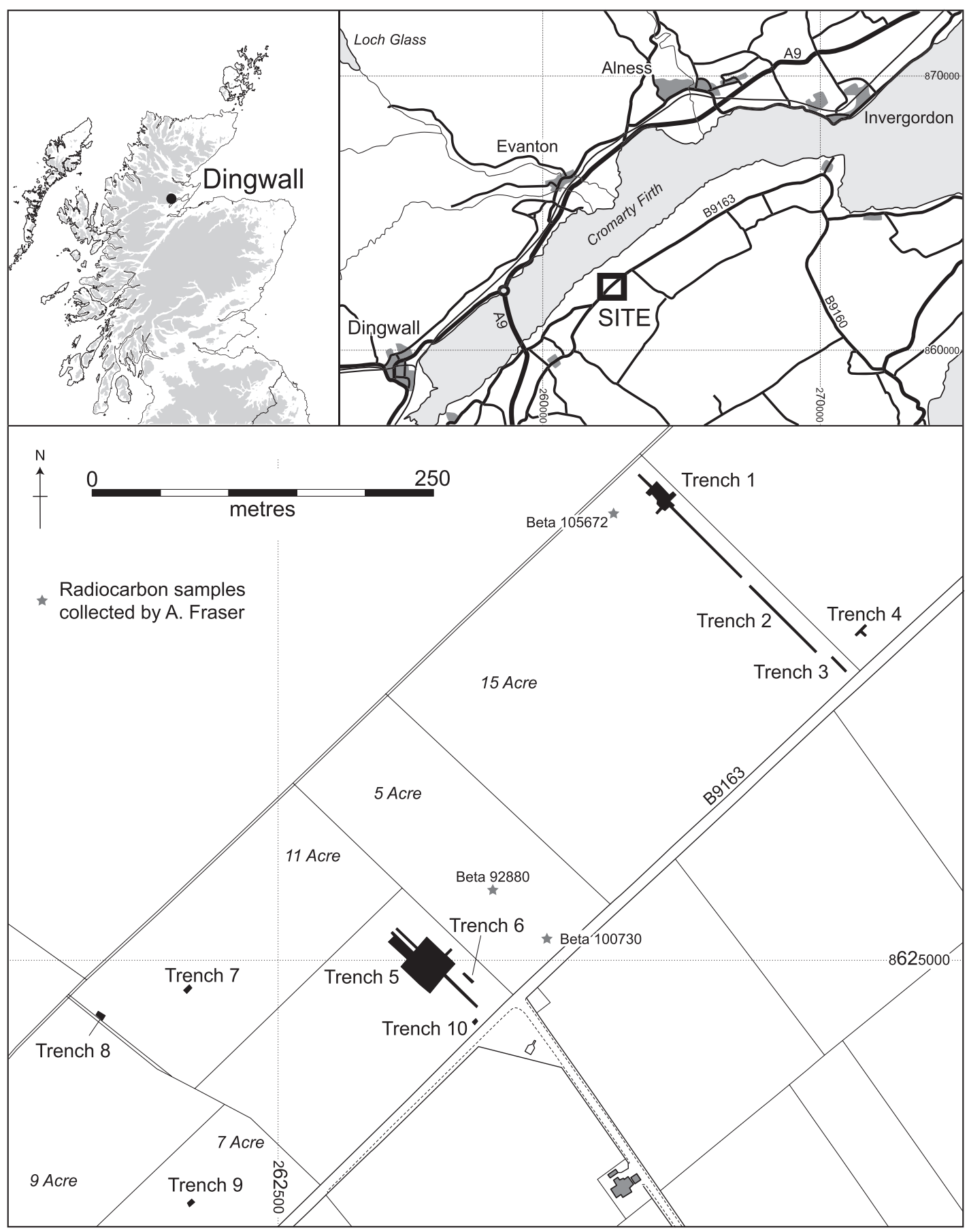

ILlus 1 Location. (Based on the Ordnance Survey map $($ C Crown copyright) 


\title{
FIELDWORK AT KINBEACHIE
}

\author{
S P Carter \& M M Dalland
}

\author{
INITIAL INVESTIGATIONS (1993-6)
}

Each year since 1993, after ploughing, Mr Andrew Fraser has walked his arable fields, collecting any flint and pottery and noting anomalous features such as stony patches or concentrations of charcoal. He undertook limited excavation of possible archaeological features and personally commissioned three radiocarbon dates on excavated charcoal (Table 1). These findings were reported to Robert Gourlay of Highland Council Archaeology and Museum Services, and their significance confirmed by Trevor Cowie of the National Museums of Scotland. In 1995 a programme of fieldwalking was initiated by Jonathan Wordsworth (then Community Archaeologist for Ross \& Cromarty) with the Rosemarkie Field Group. In 1996, following the discovery of Beaker pottery by Mr Fraser, three 3 by $2 \mathrm{~m}$ test trenches were excavated by Jonathan Wordsworth which revealed possible post-holes and a Beaker in a disturbed pit (Wordsworth 1997). This positive result, coupled with fears that ploughing was actively destroying archaeological features, prompted Historic Scotland to commission a more substantial evaluation of Kinbeachie Farm late in 1997. This work was carried out by Headland Archaeology Ltd.

\section{EVALUATION (1997)}

The initial objective of the field work in 1997 was to assess the condition, extent and nature of the archaeological remains at Kinbeachie and to propose a suitable management strategy to ensure their longterm protection. Three techniques were used: soil survey, geophysical survey and trial trenching. Selected soil-pitting and free auger survey were used to construct a soil map of the survey area. Records were made of topsoil depth, nature of subsoil and any evidence for sediment erosion and accumulation, but there was no evidence for significant recent soil movement. However, ploughing is actively truncating the subsoil throughout the farm.

A detailed magnetometer survey and a field-based magnetic susceptibility survey were carried out in sample areas and soil samples were also taken for laboratory-based magnetic susceptibility analysis; but no anomalies of likely archaeological origin were detected. As the susceptibility surveys demonstrated that the background magnetism of the site was very low the results reflect a lack of magnetic enhancement rather than an absence of archaeological features.

The trial trenches totalled $1670 \mathrm{sq} \mathrm{m}$ (illus 1). Two larger areas were opened up, one in an area of archaeological interest defined by Mr Fraser (Trench 1) where he had obtained an early Neolithic radiocarbon date (Beta-105672) and a second over the site of the 1996 evaluation (Trench 5). Eight other smaller areas were also investigated but trenching was not possible in the Five Acre Field, where Mr Fraser had obtained his other Neolithic radiocarbon date (Beta-100730). Only Trench 5 contained significant features: a concentration of truncated pits and post-holes (including a possible rectangular structure) which contained Neolithic artefacts.

\section{EXCAVATION (1997)}

Trench 5 was extended to reveal the full extent of the features and to allow excavation of them, as they were likely to be destroyed by continued ploughing (illus 2). The total area exposed was $1064 \mathrm{sq} \mathrm{m}$. The edge of a stone-quarry, first mapped by the Ordnance Survey in 1904, was revealed at the south corner of the excavated area and limited the extent of the excavation in this direction.

Stripping of the ploughsoil revealed isolated features interpreted as the bases of small ploughtruncated pits or post-holes cut into the subsoil, a shallow stony till derived from local sedimentary rocks. The cuts ranged in shape from sub-circular to more elongated shapes. The sub-circular features were generally 0.5 to $1 \mathrm{~m}$ across, but as small as $0.2 \mathrm{~m}$; the few elongated features were up to $2.5 \mathrm{~m}$ long. The features were $0.3 \mathrm{~m}$ deep at the most and the average depth was only $0.14 \mathrm{~m}$; as a result no clear profiles 


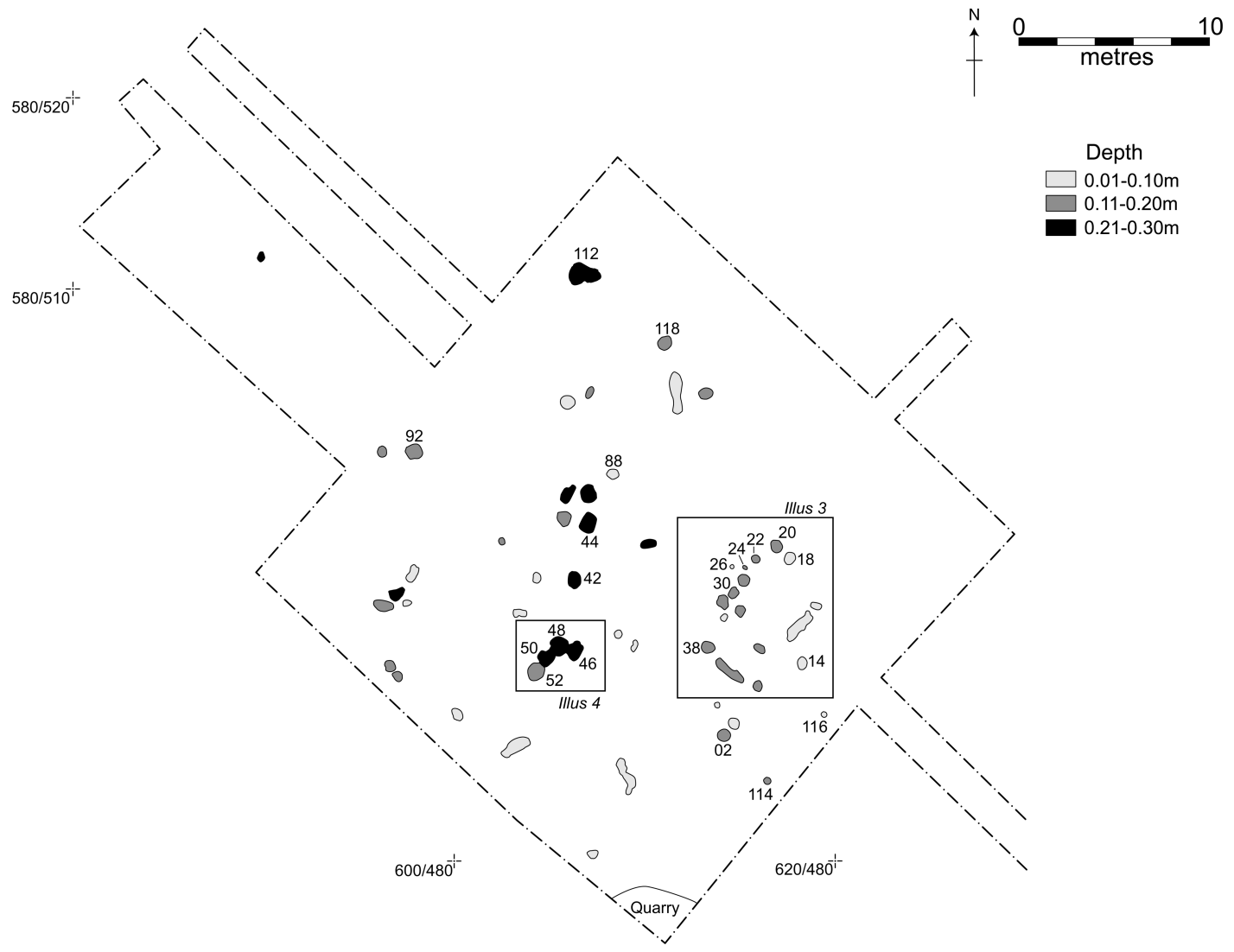

ILLUS 2 Excavated features in Trench 5

could be defined. All the elongated pits were shallow, less than $0.12 \mathrm{~m}$ deep; the larger diameter sub-circular features were generally the deepest. Most of the cut features had a uniform grey brown sandy loam fill and there was no evidence for either post-packing or post-pipes. Therefore any interpretation as pit or post-hole simply reflected the size and shape of the cuts.

Two distinct groups of features could be separated from this general, apparently random, distribution of small pits and post-holes: a rectangular structure and a group of intercutting larger pits.

\section{The rectangular structure}

The principal feature was an arrangement of shallow pits - some rounded and some elongated — which formed a 7 by $4 \mathrm{~m}$ rectangle aligned NE/SW (illus $2 \& 3$ ). The outline of this putative structure was incomplete and two corners appear to be missing. However, as the structure had been heavily truncated (the average surviving depth of the cuts making up the structure was $0.12 \mathrm{~m}$ ) it is reasonable to suggest that only the deepest cuts had survived and that others had originally existed. The cuts are 0.5 to $0.7 \mathrm{~m}$ across and may be interpreted as the bases of post-holes dug to take timber uprights, although no evidence for postpipes or post packing was recorded. At the northern end of the structure the post-holes were roughly $1 \mathrm{~m}$ apart but this apparent regularity was not maintained elsewhere. The post-holes contained a relatively high concentration of artefacts in what was an artefact-poor site. Pottery and flint flakes were recovered from five of the post-hole fills and the only high concentrations of carbonized cereal grains were also identified from this structure (illus $5 \& 8$ ). 


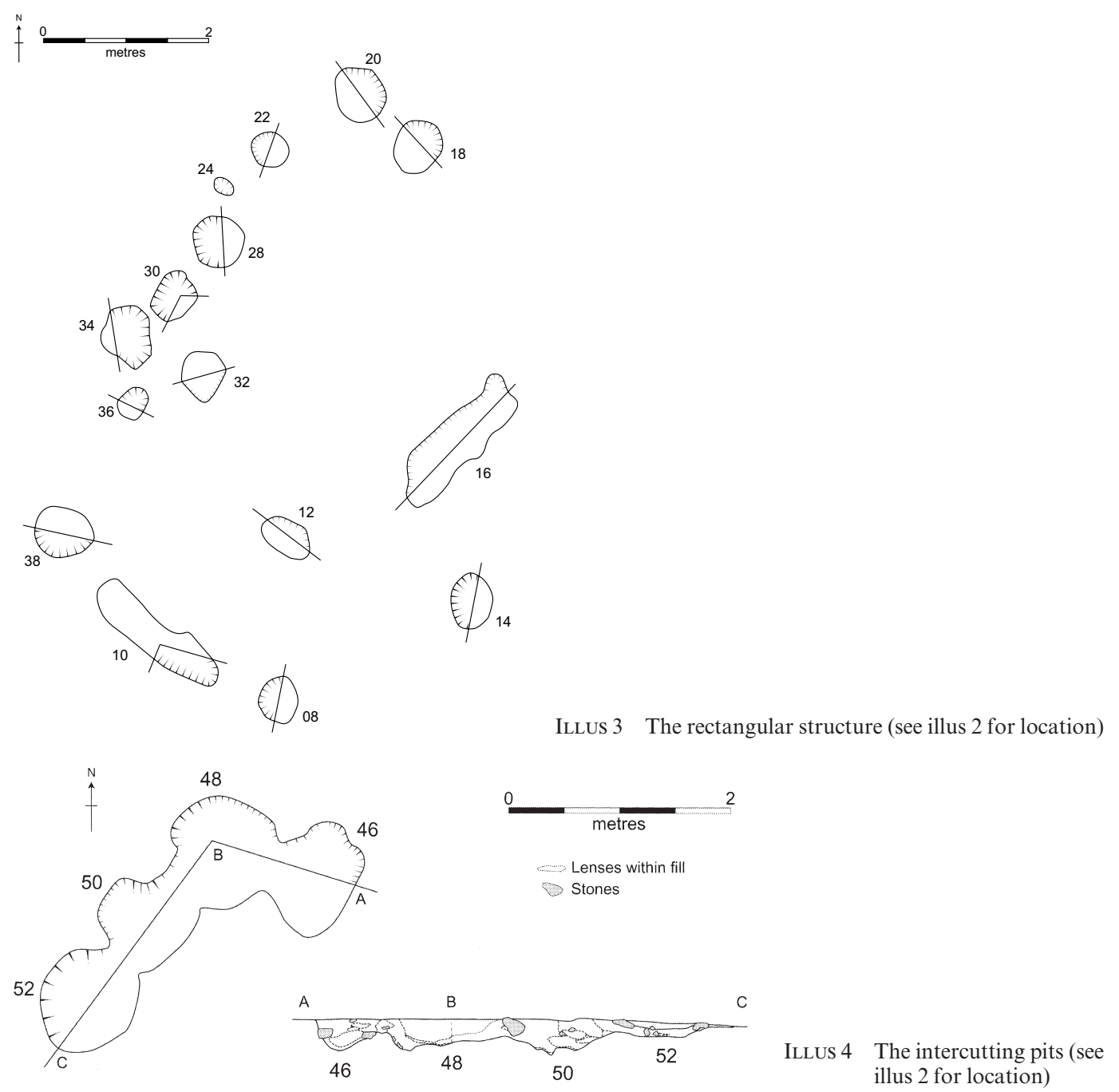

\section{Intercutting pits}

Some $6 \mathrm{~m}$ to the west of the rectangular structure there was a group of four pits: F46, F48, F50 and F52 (illus $2 \& 4$ ). These were between $0.8 \mathrm{~m}$ and $1 \mathrm{~m}$ in diameter and up to $0.3 \mathrm{~m}$ deep, and larger than most pits in the excavated area. The pits are intercutting, and are evenly spaced on a curving line. It was not possible to determine the stratigraphic relationship between the four pits, but their proximity suggests they may have been roughly contemporary, and this is supported by the distribution across the pits of sherds from the same pot. The pits contained relatively large quantities of pottery and flint flakes; one pit, F48, also contained a small polished stone axehead (illus 5). When uncovered, this pit had a rounded hollow in the middle filled with ploughsoil, as if a large round stone in the fill of the pit had been pulled out by the plough. The stone may have been deliberately placed over the polished axehead which was found near the surface of the imprint left by the stone.

No other groups of pits/post-holes could be identified with any confidence. Cuts immediately to the south of the rectangular structure may be interpreted as the remains of a second rectangle of similar size, but only five or six post-holes are present on the putative wall lines, including F2, F14, F114 and F116 as the 
four corner posts. Other possible structures can be identified amongst the scattered features, such as four features set in a square to the north of the intercutting pits (illus 2; group around F44), but the evidence is simply too slight.

\section{ANALYSIS OF THE RESULTS OF FIELDWORK}

Initial assessment of the results of the excavation and earlier fieldwork led to the definition of a programme of analysis necessary to interpret the site. Full reports, as submitted by the authors, are lodged with the site archive in the National Monuments Record for Scotland. Only elements of the reports have been selected for inclusion in this paper. In particular, the detailed catalogues for the pottery and worked stone assemblages have been omitted along with much of the analysis of the worked stone.

\section{DATING}

\section{S P Carter \& M M Dalland}

All of the artefacts recovered during the excavation were consistent with a Neolithic date for the site but the 1996 evaluation had demonstrated the presence of Beaker pottery nearby and later activity could therefore not be ruled out. The material available for dating was limited to small quantities of carbonized plant remains recovered from pit and post-hole fills by flotation of bulk sediment samples (illus 8). No examples of in situ burning were identified during excavation and all of the carbonized plant remains were assumed to have been re-deposited and consequently to represent material of mixed age. Therefore it was decided to obtain six accelerator determinations on single entities. Barley grains and fragments of hazel nut shell were selected from six different fills: three from features of the possible rectangular structure, two from the pit group, and one from another pit/post-hole, F2 (illus 2). Details of these samples and the results obtained are presented in Table 1.

The six accelerator determinations form a close group with central uncalibrated values between $4575 \pm 45 \mathrm{BP}$ and $4450 \pm 40 \mathrm{BP}$. Calibration of the dates gives a calendrical age range of 3500 to $2920 \mathrm{BC}$ at the $95.4 \%$ confidence level. There is no significant difference in age between material types or context and it can be concluded that all of the samples derive from the same period within the resolution of the dating technique. This result is entirely consistent with the other evidence for dating and suggests that, while some un-dated cut features may be of different date, along with the Beaker pit, this is essentially a single period Neolithic site.

\section{POTTERY}

\section{A MacSween}

\section{POTTERY FROM THE 1997 EXCAVATIONS}

A Neolithic Impressed Ware assemblage (total weight $1.2 \mathrm{~kg}$ ) was recovered from two main areas of the site - pits F46, F48 and F50, and the rectangular structure (illus 5). The pottery was very fragmentary and abraded, but sherd-matching led to the identification of 16 vessels - sherds from at least five vessels were recovered from the pit group, sherds from eight vessels from five post-holes associated with the timber structure (F16, F18, F22, F32 \& F38), and sherds from three further vessels from pits in other parts of the site (F44, F88, F124 \& F126).

Where vessel shape could be reconstructed, the pots had flat rims, some slightly splayed, the flat part often being decorated. Below the lip the vessel curved slightly inwards and then outwards to a carination. Where the position of the decoration could be determined, it was restricted to the flat part of the rim and the area between the lip of the vessel and the carination. No basal fragments were found.

A variety of techniques had been used to decorate the vessels. Vessel 1 (V1) (illus 6) has corrugated decoration with a herringbone effect possibly resulting from a spatula being pressed down to form the 
TABLE 1

Radiocarbon dates

\begin{tabular}{|c|c|c|c|c|c|}
\hline $\begin{array}{l}\text { Lab sample } \\
\text { no }\end{array}$ & Context & Description & Material & $\begin{array}{l}\text { Radiocarbon } \\
\text { Age }(\mathrm{BP})\end{array}$ & $\begin{array}{l}\text { Calibrated age } \\
\text { ranges }(95.4 \%)\end{array}$ \\
\hline \multicolumn{6}{|c|}{ Dates obtained from samples from 1997 excavation at Kinbeachie } \\
\hline OxA-8202 & 1 & Post-hole/pit & $\begin{array}{l}\text { Corylus avellana nut } \\
\text { shell }\end{array}$ & $4560 \pm 40$ & $\begin{array}{l}3500-3480 \mathrm{BC} \\
3380-3100 \mathrm{вC}\end{array}$ \\
\hline OxA-8203 & 21 & Post-hole of structure & $\begin{array}{l}\text { Corylus avellana nut } \\
\text { shell }\end{array}$ & $4450 \pm 40$ & $\begin{array}{l}3340-3220 \mathrm{BC} \\
3190-3020 \mathrm{BC} \\
3000-2920 \mathrm{BC}\end{array}$ \\
\hline OxA-8204 & 37 & Post-hole of structure & Hordeum sp grain & $4575 \pm 45$ & $\begin{array}{l}3500-3410 \mathrm{BC} \\
3380-3100 \mathrm{BC}\end{array}$ \\
\hline OxA-8205 & 47 & Pit group & $\begin{array}{l}\text { Corylus avellana nut } \\
\text { shell }\end{array}$ & $4530 \pm 45$ & $\begin{array}{l}3370-3090 \mathrm{BC} \\
3060-3040 \mathrm{BC}\end{array}$ \\
\hline OxA-8206 & 49 & Pit group & Hordeum sp grain & $4455 \pm 40$ & $\begin{array}{l}3340-3220 \text { вС } \\
3200-3020 \text { вС } \\
2990-2930 \text { вС }\end{array}$ \\
\hline OxA-8415 & 17 & Post-hole of structure & Hordeum sp grain & $4565 \pm 45$ & $\begin{array}{l}3500-3420 \text { вС } \\
3380-3100 \text { вС }\end{array}$ \\
\hline \multicolumn{6}{|c|}{ Dates obtained by Mr A Fraser from features excavated between 1993 and 1997} \\
\hline Beta-92880 & $\begin{array}{l}5 \text { Acre field } \\
\text { cNH } 62656255\end{array}$ & Charcoal-rich feature & Wood charcoal & $790 \pm 50$ & AD1150-1300 \\
\hline Beta-100730 & $\begin{array}{l}5 \text { Acre field } \\
\text { NH } 62696252\end{array}$ & Burnt deposit in stone spread & Wood charcoal & $4380 \pm 60$ & $\begin{array}{l}3300-3235 \mathrm{BC} \\
3115-2890 \mathrm{BC}\end{array}$ \\
\hline Beta-105672 & $\begin{array}{l}15 \text { Acre field } \\
\text { NH } 62786284\end{array}$ & Isolated pit & Wood charcoal & $4930 \pm 50$ & $3795-3640$ вс \\
\hline
\end{tabular}

corrugations. In this case the rim is decorated with two rows of oblique incisions. The band of corrugated decoration is punctuated by a row of perforations. On three vessels (V2, V5 \& V10: illus 7), the decorated band comprises oblique grooves made with a blunt implement, two rows on V5 and V10. V3 is also decorated with oblique incisions, but this time more finely executed and with further incisions on the lip. Dshaped impressions were noted on the rim of V6 (illus 7) which also had an incised cordon.

Most of the vessels are made of a mix of fine sandy clay with $10-30 \%$ of angular rock fragments which has usually fired hard and is reduced (grey) with oxidized margins (red/buff/brown). V1 exhibits fire cracking in the interior, indicating that it was exposed to a greater heat than might have been expected from a cooking fire. Sooting was noted on nine vessels indicating that they were used for cooking.

\section{CONTEXT}

Pit group

Four of the five vessels from the pit group (V1, V2, V3 \& V5) are from decorated, carinated vessels. Sherds from two of the vessels, the corrugated decorated vessel (V1) and a vessel decorated with grooved incisions (V2), were recovered from two pits - V1 had sherds in F46 and F50 and V2 had sherds in F46 and F48. Sherds from a vessel with a splayed rim and decorated with incised lines (V3) were recovered from F50 as were a couple of undecorated sherds from a different vessel (V4). A rim sherd from a carinated vessel decorated with oblique grooves (V5) was recovered from F48.

\section{Rectangular structure}

The pottery associated with the rectangular structure is from five possible post-holes. The remains of one vessel, V6 the cordoned vessel with the D-shaped stamps on the rim, were recovered from F16. A number of 


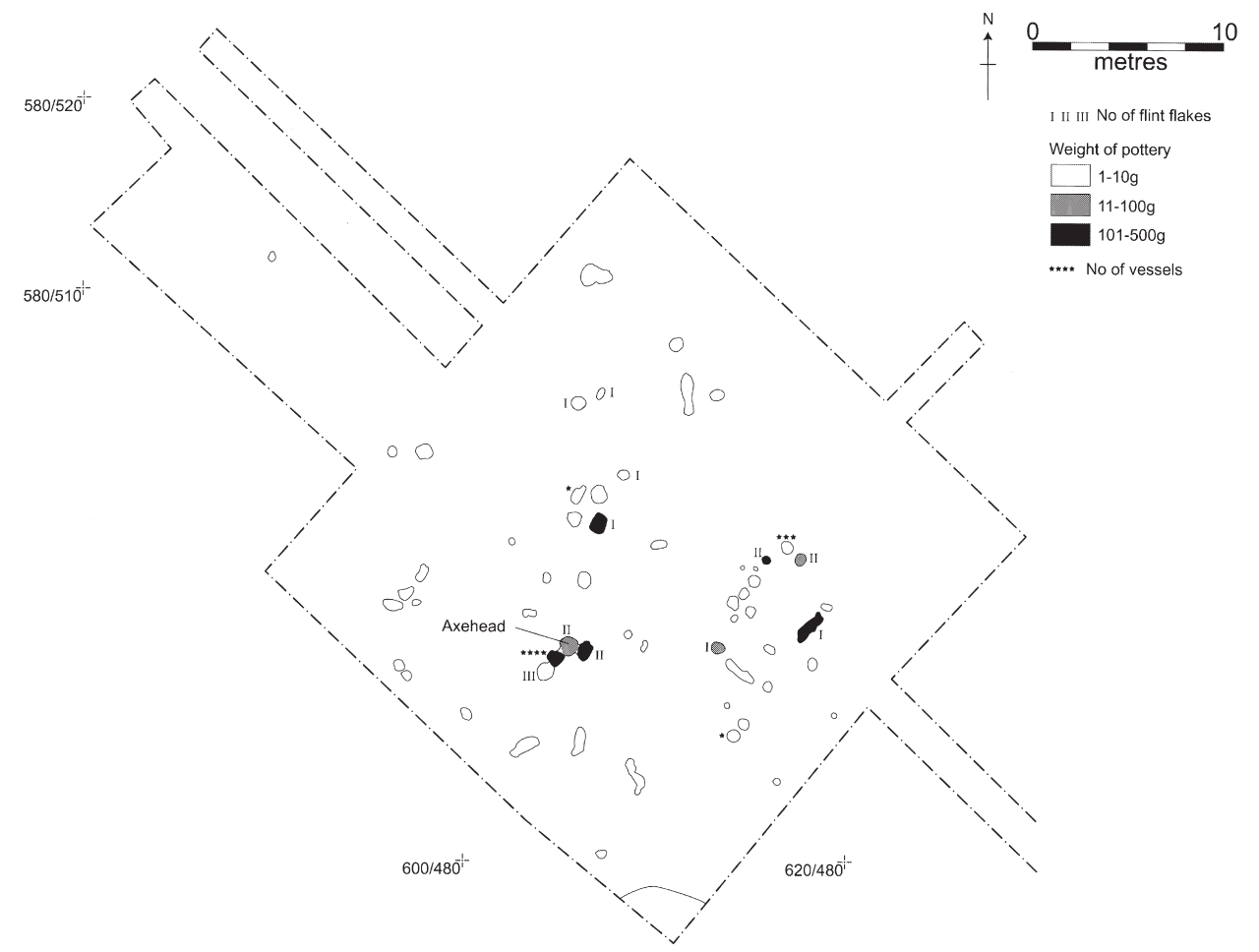

ILLuS 5 Distribution of artefacts in Trench 5

undecorated sherds from one vessel (V7) were recovered from F38 while a couple of fine sherds from a vessel decorated below the lip (V8, illus 7) and a few sherds from a thick-walled vessel (V9) were recovered from F18. Three vessels were represented in F22 - a vessel decorated with short grooves (V10) and two vessels represented by undecorated fragments (V11 \& V12). Finally, F32 had one undecorated body sherd (V13).

\section{Pottery from other contexts}

Pottery was also recovered from four pits/post-holes to the north of the group of pits already described F44 had 25 undecorated sherds (V14: two further sherds from the same vessel were found in F126); an undecorated body sherd (V15) was recovered from F88; and three abraded sherds (V16) from F124.

\section{POTTERY FROM FIELD COLLECTION AND 1996 EXCAVATIONS}

The pottery from the field collections shows that the repertoire of motifs on the Impressed Wares from the site is wider than represented in the assemblage from the 1997 excavations. A sherd from a vessel similar to those recovered during the excavation is included in the collection (1091:42, illus 7), decorated with fingernail impressions arranged in two horizontal rows above the carination, with a further row on the lip of the vessel. This vessel, like V1, has a row of perforations around its upper section. A badly abraded sherd (1091:44, illus 7) appears to be decorated with bird bone impressions.

Material from the 1996 excavations comprised the remains of a Beaker, too fragmentary for reconstruction, decorated in zones to just above the base. Sherds include some from the neck and base, but 

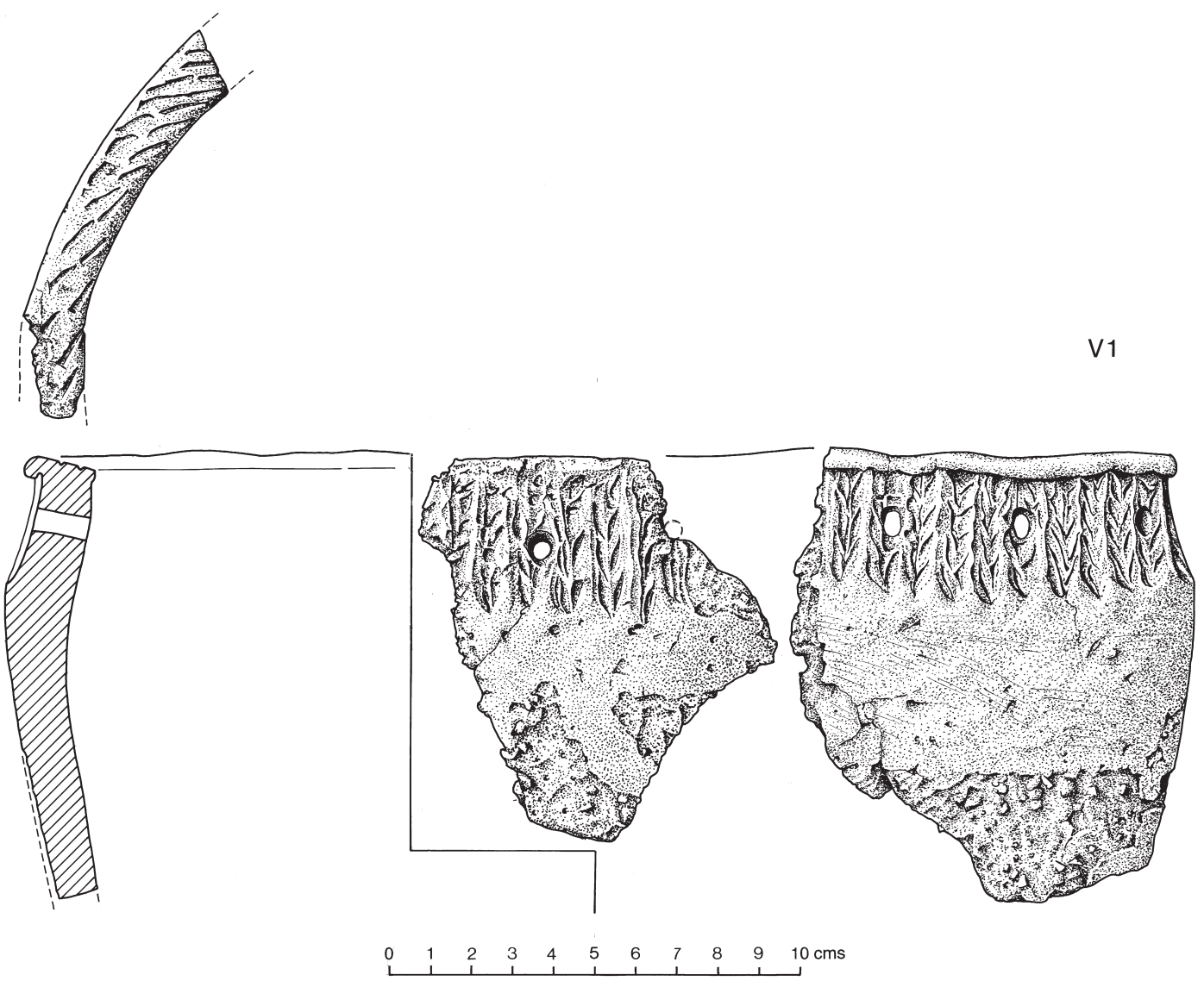

ILlus 6 Pottery: Vessel 1

none from the rim. Zones include a line of closely-spaced vertical incisions banded with horizontal lines of comb impressions and incised herringbone decoration also banded with comb impressions.

\section{CARBONIZED PLANT REMAINS}

\section{T Holden \& M Hastie}

Carbonized plant remains were recovered from 19 sediment samples (illus 8). In addition to wood charcoal, most of the samples contained the remains of cereal crops and other economic species (Table 2). Seeds of agricultural weeds and plants from non-agricultural habitats were almost totally absent.

\section{CEREALS}

Three types of cereal grain were present in the samples, primarily naked barley with much lesser quantities of emmer wheat and a few grains identified as hulled barley. Most of the naked barley grain was straight (ie symmetrical) indicating dominance of the two-rowed form. However, the presence of a number of twisted grains suggests the presence of a significant proportion of grain from a six-rowed variety. Wheat grain was present in small numbers from seven samples but was generally poorly preserved. Nevertheless, grains that 

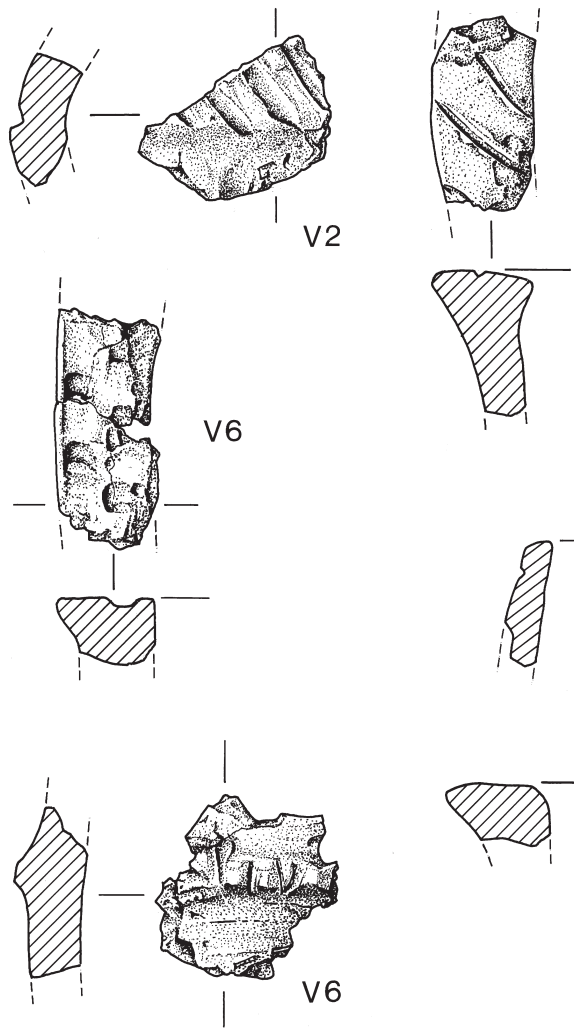

V3
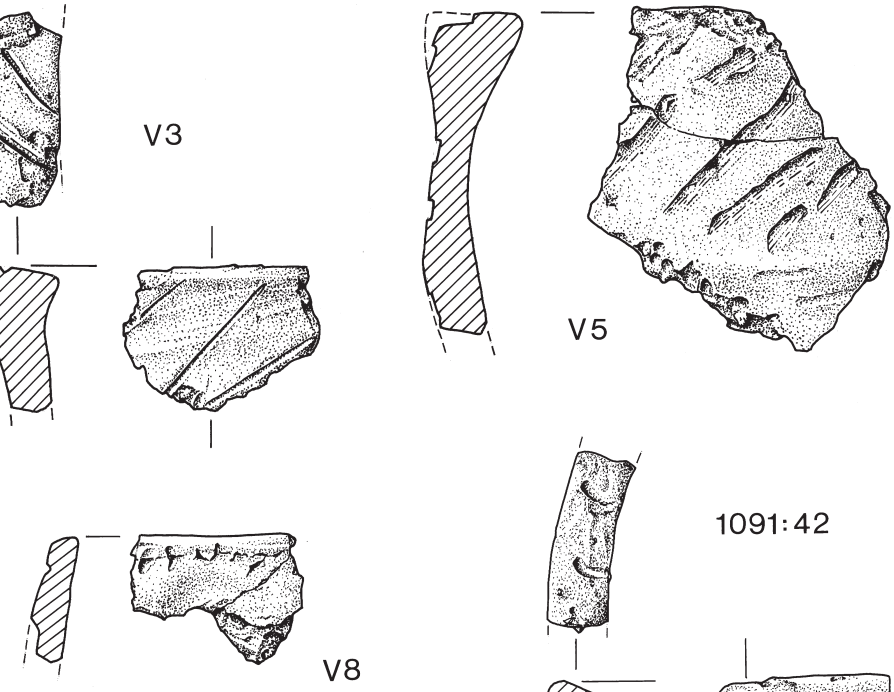

V8

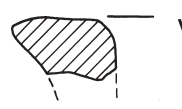

V10
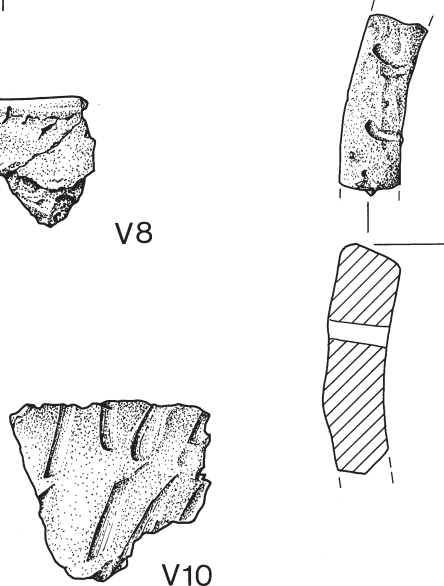

1091: 42

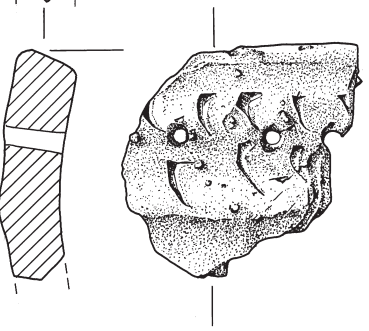

$29: 9$
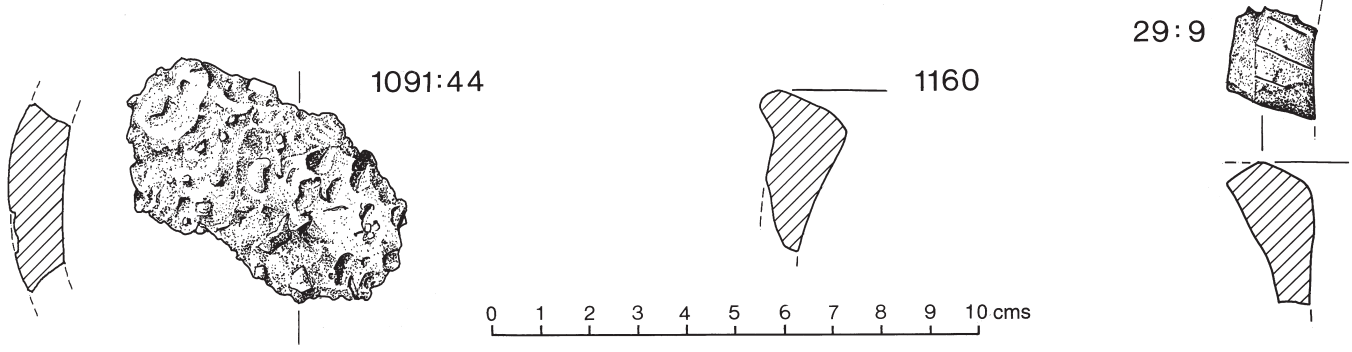

\begin{tabular}{lllllllllll}
0 & 1 & 2 & 3 & 4 & 5 & 6 & 7 & 8 & 9 & 10 \\
\hline
\end{tabular}

ILLus 7 Pottery: Other decorated vessels

were morphologically typical of emmer were recovered. Only three grains that could be ascribed to hulled barley were encountered.

Some context-related variation across the site was apparent and this may have a bearing on the interpretation of the archaeological features. Two samples stand out with respect to concentration of cereal grain, both naked barley and emmer. These are the fills of post-holes F20 and F22 in the north corner of the rectangular structure (illus 8). Although a number of post-holes on the south side of the structure were so poorly defined that it was not possible to provide a well-sealed fill for analysis, samples from relatively wellpreserved features such as F30 and F38 did not contain significant quantities of charred grain. This confirms that the burnt grain was concentrated in the north corner. The low concentrations of grain in many of the features surrounding this structure would be consistent with grain that had been spread by human or other means from the high concentration close to F20 and F22. 


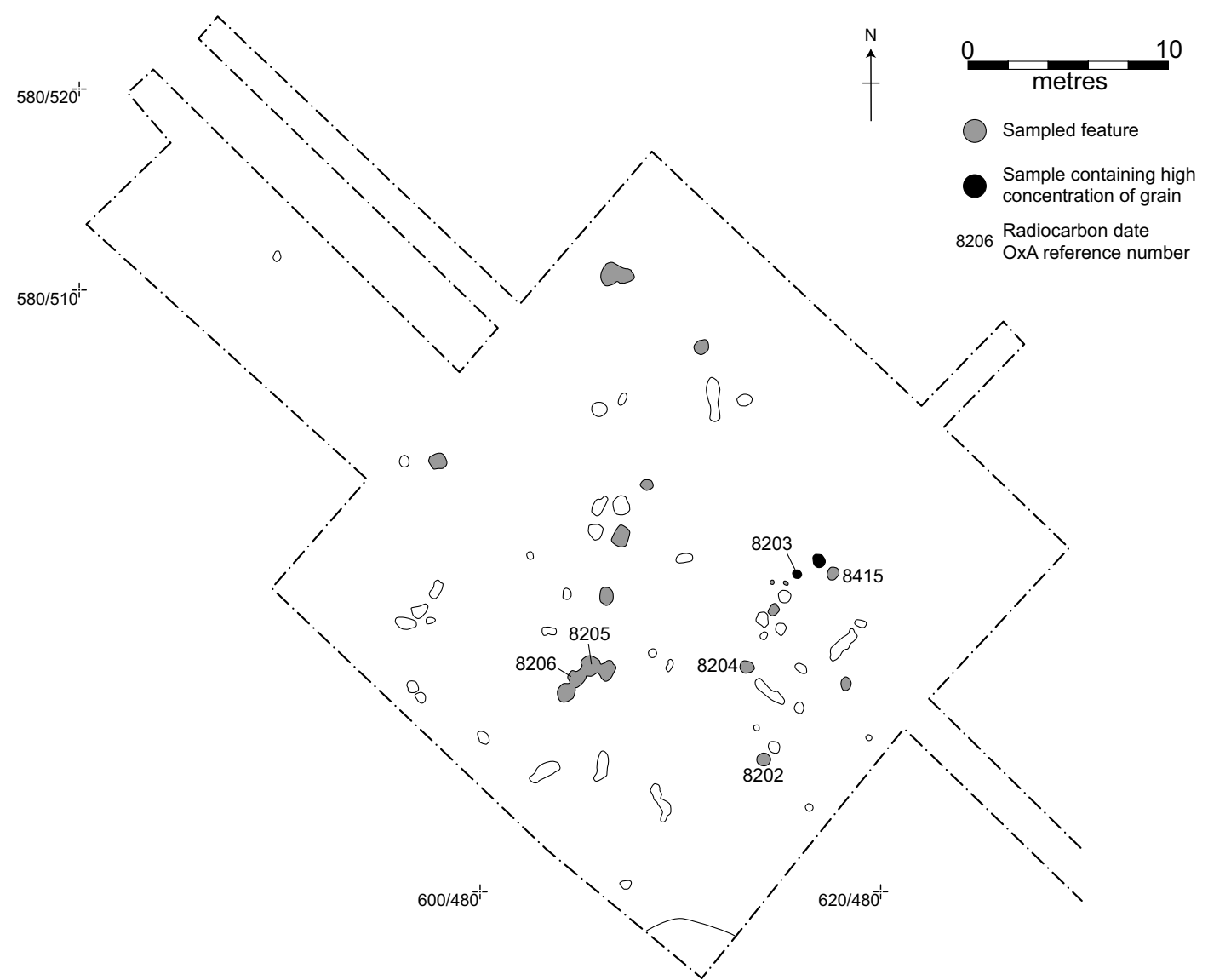

ILLUS 8 Location of samples

\section{OTHER POSSIBLE ECONOMIC SPECIES}

Fourteen out of the 19 sediments sampled contained the remains of hazel nuts and one sample also contained the degraded stone of a species of Prunus, a genus which includes sloe, bird cherry and a number of domesticated fruit trees. The distribution of nut shell does not match the cereal grain and indicates that it does not derive from the same accidental burning. The nut shells and Prunus stone are likely to represent food debris discarded onto the fire.

\section{DISCUSSION}

The cereal samples are dominated by naked barley with some emmer wheat. Although the number of excavated Scottish Neolithic sites from which the plant remains have been analysed is not great these two cereals are the dominant component at all. In view of the generally poor condition of much of the grain from Kinbeachie the absence of chaff is likely to be a result of poor preservation. It is therefore impossible to comment on the consumer versus producer status of the site on the basis of the cereal remains alone. The charred grain is concentrated in two postholes in the northern corner of the rectangular structure. The lack of weed seeds in these two samples suggests that this was a clean processed barley crop. There is no evidence that would 
68 SOCIETY OF ANTIQUARIES OF SCOTLAND, 2001

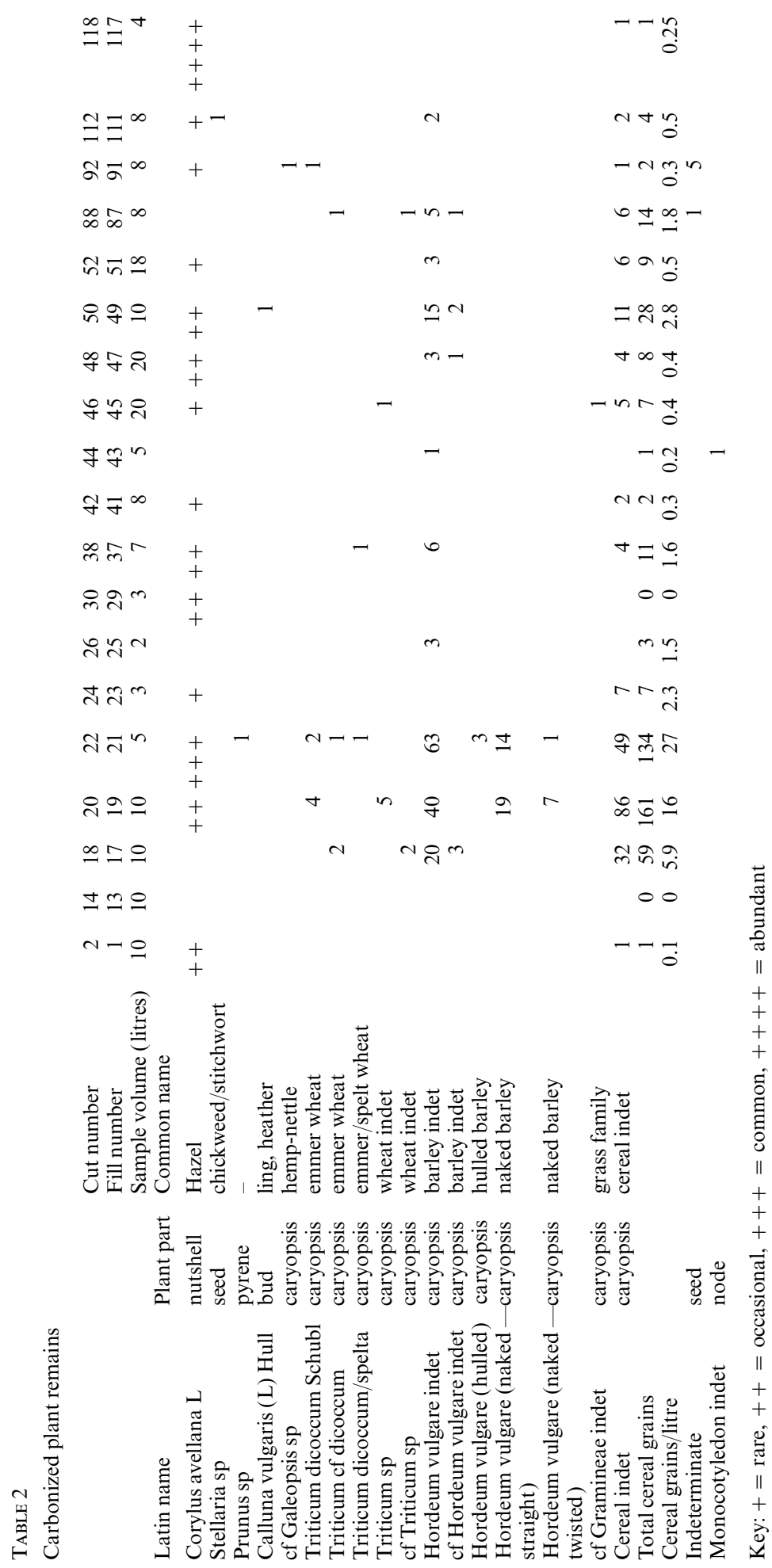


suggest that the structure itself had burnt down but it seems likely that the charred grain was the result of accidental charring, possibly during small-scale corn drying. It is possible that this small patch of concentrated burnt grain is the source of much of the low concentration of charred material from other contexts on the site.

Published studies of cereal grain recovered from Neolithic sites in Scotland report varying proportions of barley and emmer wheat. At present the limited pool of available data makes it impossible to determine whether the dominance of one cereal over the other was a result of regional differences or a temporal trend brought about by changes in society, agricultural practice or climate, or was within the normal range of variation. At Balbridie, Aberdeenshire, for example, around $4000 \mathrm{cal} \mathrm{BC}$ emmer was by far the dominant cereal comprising $80 \%$ of the total grain with naked barley making up only $18 \%$; one remarkable assemblage from Balbridie is dominated by bread wheat (Fairweather \& Ralston 1993). Other assemblages such as those from a Neolithic pit at Lairg, Sutherland (3290-2930 cal BC; Holden 1998) were also dominated by emmer whereas that from Boghead mound, Moray (4000-3500 cal BC: Maclean \& Rowley-Conway 1984), contained primarily naked barley. In the case of Kinbeachie, the distribution of grain on the site suggests that it mostly derived from a single accidental burning of a clean barley crop. The few grains of emmer mixed in with the barley may be contaminants left over from a previous crop in the same field. If site assemblages can be dominated by grain from a single crop it suggests that the balance between carbonized barley and wheat on any one site is unlikely to reflect the areas of different cereal crops grown in the longer term.

\section{WORKED STONE}

\section{Wickham-Jones}

\section{CONTEXT AND COLLECTION}

Fifty pieces of worked stone have been recovered from Kinbeachie Farm; all are pieces of flaked stone except for a small polished axehead of metamorphic rock. The assemblage is almost equally divided between pieces recovered from field-walking (54\%), and pieces recovered from the 1997 excavation (46\%) (Table 3 ).

TABLE 3

Worked Stone: breakdown of the assemblage by recovery method

$\begin{array}{lccc} & \text { Field-walking } & \text { Excavation } & \text { Total } \\ \text { Pebble } & 1 & & 1 \\ \text { Chunks } & 4 & 5 & 4 \\ \text { Debitage Flakes } & & 13 & 5 \\ \text { Regular Flakes and Blades } & 16 & 4 & 29 \\ \text { Retouched Pieces } & 6 & 1 & 10 \\ \text { Axehead } & 27 & 23 & 50 \\ \text { Total } & & \end{array}$

The two sub-assemblages appear to be part of the same general assemblage, although the pieces are spread pretty thinly on the ground. The field-walking material contains a higher proportion of retouched pieces, and the excavated material contains a higher proportion of debitage, but the differences are very small and may relate to the different methods of recovery. It is notable that all the pieces from contexted features in the 1997 excavation were flakes, both regular and debitage, with the exception of the axehead. All of the retouched tools were recovered from the ploughsoil. 


\section{THE ASSEMBLAGE}

The flaked stone comprises mainly flint ( 39 out of 49 pieces), supplemented by chalcedony, quartz, quartzite and pitchstone in small quantity. All the retouched pieces were of flint. There is no direct evidence that any of these other materials were knapped on site, but the chalcedony, quartz and quartzite are likely to have been local materials occasionally used to supplement the flint, and worked in similar fashion to produce regular flakes. The pitchstone, which was represented by regular blades, is not a local material and the main geological source is the island of Arran. Pitchstone artefacts, mainly blades, occur on many Neolithic sites right across Scotland as far as Orkney (Richards, forthcoming).

$\begin{array}{llr}\text { TABLE } 4 & \\ \text { Lithic Assemblage: } & \text { correlation between material and type } \\ \text { Material } & \text { Type } & \text { Quantity } \\ \text { Flint } & \text { Pebble } & 1 \\ & \text { Debitage Chunks and Flakes } & 8 \\ & \text { Regular Flakes } & 20 \\ & \text { End Scraper } & 1 \\ & \text { Edge Retouched } & 3 \\ & \text { Leaf Point } & 1 \\ \text { Chalcedony } & \text { Serrated } & 2 \\ \text { Quartz } & \text { Regular Flakes } & 3 \\ \text { Quartzite } & \text { Regular Flakes } & 2 \\ \text { Pitchstone } & \text { Regular Flakes1 } & \\ & \text { Blades } & 3 \\ & \text { Debitage Chunk } & 1\end{array}$

\section{Flint}

In general the flint is good quality and it is likely that a local source of pebble flint was used; the use of pebble flint is confirmed by the surviving cortex which is very abraded. Much of the flint assemblage comprises retouched tools and there is little debitage (Table 5). Knapping generally involved the use of a platform core, indeed the flakes indicate that cores were carefully maintained as most have signs of edge trimming at the proximal end and one or two have faceted platforms. In addition to the regular flakes three of the retouched pieces are made on blades. This is not enough to suggest that the knappers were practising blade technology, but they were clearly able to produce a variety of good quality flakes and blades, suitable for use un-altered, or to act as blanks for further work.

$\begin{array}{lc}\text { TABLE } 5 & \\ \text { Worked stone: breakdown of the flint assemblage by type } \\ \text { Type } & \text { Quantity } \\ \text { Pebble } & 1 \\ \text { Chunks } & 3 \\ \text { Debitage Flakes } & 5 \\ \text { Regular Flakes } & 20 \\ \text { Edge Retouched } & 4 \\ \text { Scrapers } & 3 \\ \text { Serrated Blades } & 2 \\ \text { Bifacial Leaf Point } & 1 \\ \text { Total } & 39\end{array}$

Ten of the flint artefacts have been altered by retouch, probably using pressure flaking. There are three scrapers (illus 9, nos $1,2 \& 3$ ). One is a small round flake with a scraping edge worked almost around the entire circumference (illus 9 , no 1 ). Another is made on a chunky primary flake, with a rounded scraping edge worked around the right, distal and proximal edges (illus 9, no 2). Finally, there is a short, stubby end 

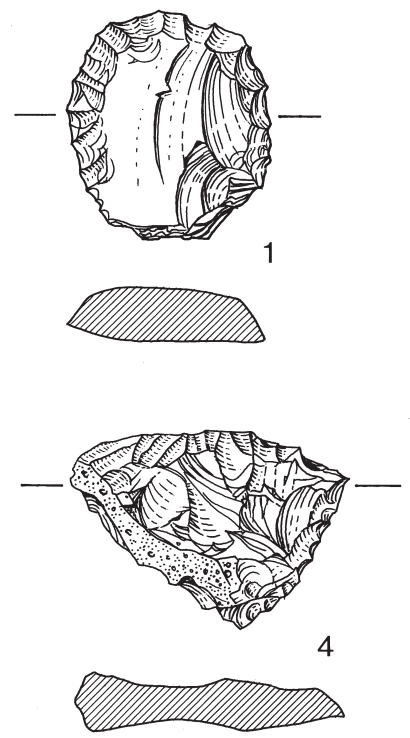

\begin{tabular}{lllll}
0 & 1 & 2 & 3 & 4 \\
\hline
\end{tabular}
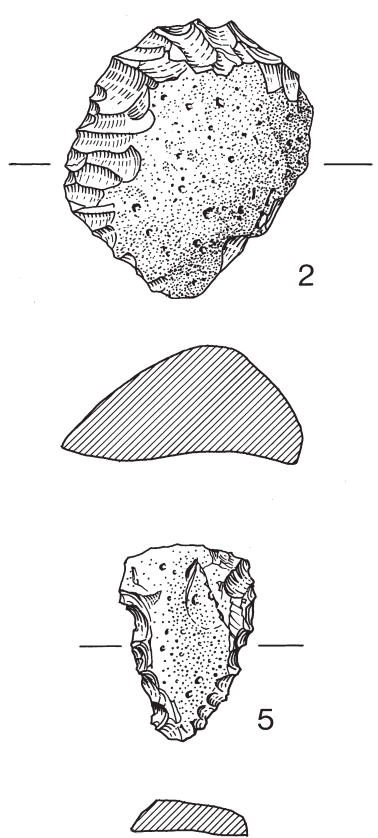
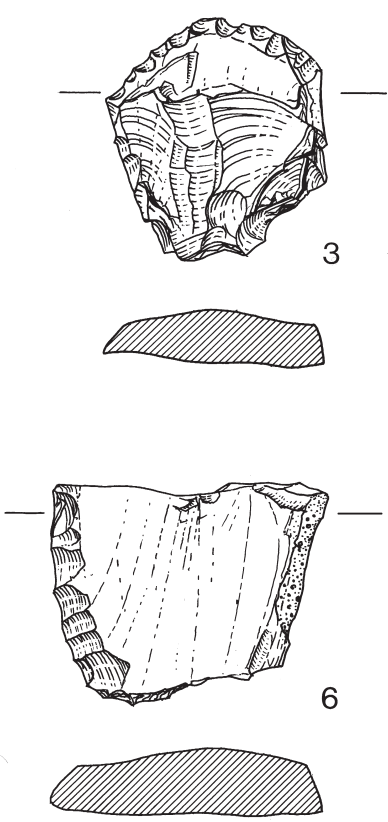

ILLus 9 Worked stone. 1-3: Scrapers 4-6: Edge Retouched Pieces

scraper with a rounded scraping edge opposite a narrow butt which has been partially retouched into shape (illus 9, no 3).

Four pieces have been classified as edge retouched pieces though they show little superficial similarity one to another. Two (illus 9 , nos $4 \& 5$ ) are markedly triangular in shape with steep edge retouch around two sides and one cortical edge. One (illus 9, no 6) is made on a larger flake and has fine edge retouch up one straight side, but it has been snapped, and it is therefore impossible to tell the size or shape of the original piece. This piece has a faceted platform, a technique found elsewhere in the Neolithic, and the proximal end has some damage, possibly indicative of its use as a strike-a-light.

There are two serrated blades made on long blade segments (illus 10 , nos $2 \& 3$ ). One has minute serrations along the right side and there is visible gloss along the base of these serrations on the ventral surface (illus 10, no 2). The other has tiny, steep edge retouch which produces irregular serrations along both edges and there is clear gloss visible along the left side on the ventral surface (illus 10, no 3 ).

Finally, there is one bifacial leaf point (a 'leaf-shaped arrowhead') (illus 10, no 4) measuring 20 by 20 by $3 \mathrm{~mm}$. This is made on good quality orange-red flint and has fine bifacial flaking to thin and shape it. It has a wide rounded base and tapers towards a long, slender point. Though the actual tip is missing it is possible to place it among Green's Class 3B arrowheads (Green 1980, though he did not look in detail at Scottish material). Just above the widest point there are minute notches in the edge which may be related to hafting, though they could also be accidental damage. Similar notches have been recorded on some flint daggers (eg Edmonds 1995, 144-5).

\section{The axehead}

The axehead (illus 10, no 1 ) is made from a small polished flake of a fine-grained metamorphic rock; it measures 43 by 31 by $11 \mathrm{~mm}$. The raw material must have originated from a small outcrop of a metamorphosed porphyritic dyke, with amphiboles and altered feldspars in a fine grained matrix. It is common north of the Highland Boundary Fault, and it is likely that this piece was derived from a local source, probably as a cobble from a local drift deposit. 

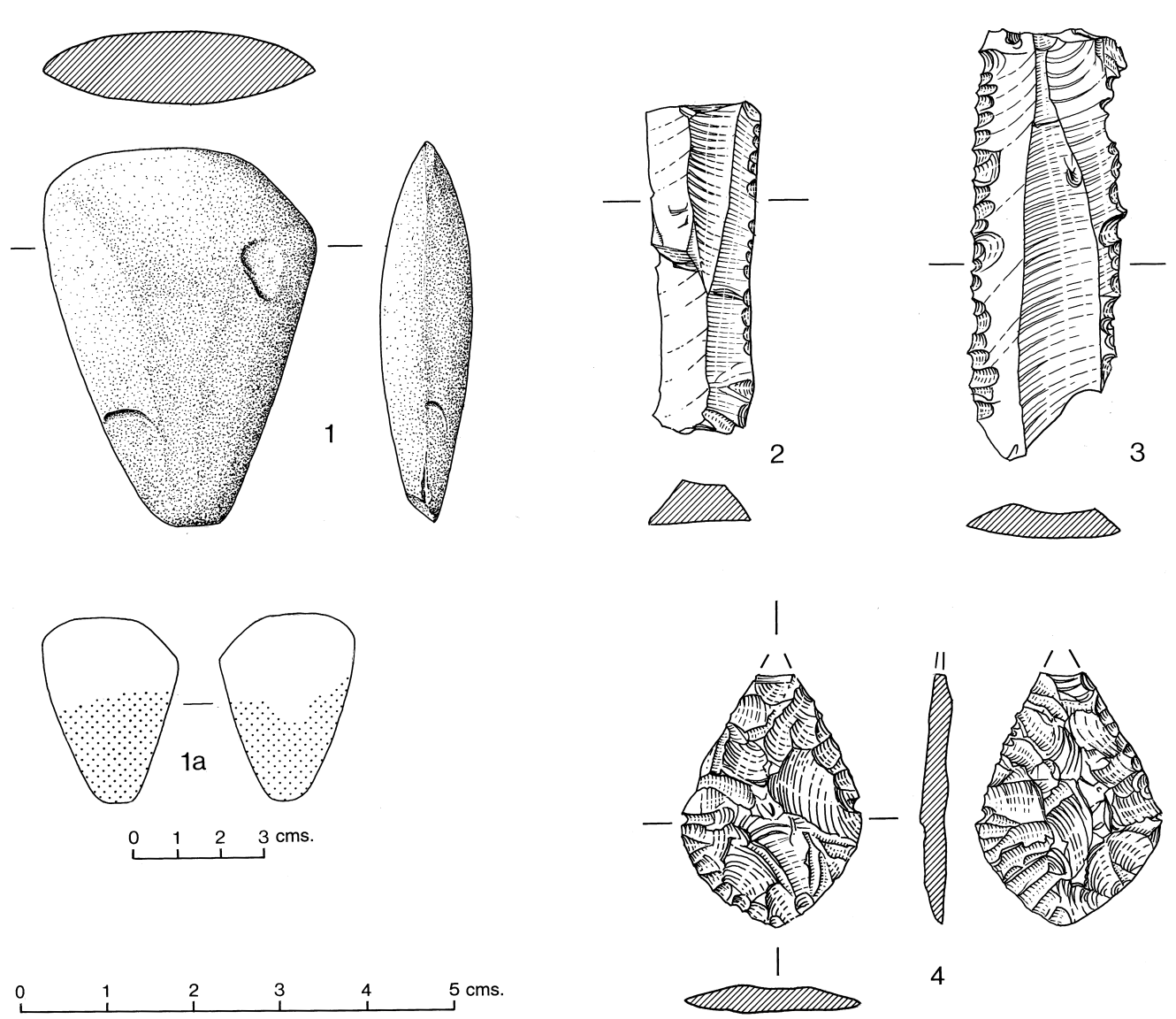

ILlus 10 Worked stone. 1: Axehead (1a: extent of discolouration) 2, 3: Serrated Blades 4: Bifacial Leaf Point

The axehead has a narrow rounded butt and a broad slightly convex 'blade'. As there are striations from polishing in the small scars along the edge it would appear to be unused or only very lightly used. The butt has been slightly damaged, and there is damage at one side of the working edge, but nothing indicating what we might regard as 'normal' functional use of an axe; the damage may have been caused by some other action or may be post-depositional. The sides are slightly flattened, probably due to the action of polishing. It has been polished to a smooth surface all over, though it is just possible to discern remnant scars from the original flaking which must have been used to shape it. There is no evidence that the axehead has been worked down from a larger tool.

A clear discolouration is visible on the surface of the axehead over approximately half of its length at the butt end (illus 10, no 1a). This may be an indication that it was hafted. Similar discolorations have been a sign of the use of mastic on a tool, but no trace of this was detected in the wear analysis by Finlayson.

\section{INTERPRETATION OF THE ASSEMBLAGE}

The assemblage is very small considering the area across which material has been recovered, and it contains very little debitage ( $20 \%)$; and it would therefore seem to have resulted in general from the use of tools rather than their manufacture. This is, by and large, supported by the use-wear analysis by Finlayson (see archive report). Of the small sample selected for examination there 
were only three apparently unused pieces, one of which was the axehead. As small axes are unlikely to have been functional it may well relate to a special deposit (see below). The other two are a scraper and an edge retouched tool, both of which could be argued to have been freshly made and awaiting use. Any collection of tools is likely to include newly made pieces, as well as half used pieces and others which are ready to be discarded.

Of the used tools, it is suggested that the use-wear analysis may indicate that the two serrated tools both appear to have been used to cut grasses or cereals. Despite the saw-like serrations, their use appears to have involved a cutting motion, transverse to the long axis of the tool. One piece has had both sides used. Assuming that these tools could be re-hafted and the unused edge used, it is likely that an element of retooling would have been conducted, but it is impossible to say whether this would have been done in a settlement or in the field. The only clue here may be the relatively minor use of one side, which might imply that the re-hafting was a stopgap measure, merely to get a job finished, rather than for longer use. The scarcity of such pieces on settlement sites may be the result of off-site use in harvesting, where the bulk of discards is likely to have taken place. This would be supported by the author's observation that most of these tools are found as isolated finds away from obvious or known archaeological sites.

The debitage element of the assemblage comprises the accidental by-products of knapping (flaked pebbles, cores, chunks, and small, irregular flakes). As debitage is often small and irregular the lack of it among the present material may be related to the fact that much of it was collected by field-walking. Field-walking, especially in the past, tended to 'cherry-pick' better, more obvious pieces, thus biasing any flint collection. However, debitage is also lacking in the area of excavation, where better conditions for the recovery of flaked stone were backed up with the use of sieving. It is likely that, in this area at least, the lack of debitage is real. Elsewhere on the farm it is possible that some debitage may have been missed, though it seems unlikely that any great concentration, had it been obvious on the surface, would not have been noticed given the known interest in flaked stone of those involved with the site throughout its recent history. The recovery of three tiny pitchstone blades from field-walking in 1995 would support this view.

The assemblage includes one polished tool, a small axehead, as well as the flaked artefacts. Small axes are problematic in that their role in a British context has not been well studied. Traditionally it has been assumed that they did not have a practical role, but rather served as talismans or toys (Edmonds, pers comm). On the other hand, many have been worked down from larger axes as repeated resharpening has reduced their size. There is no evidence that this was the case here, however, and use-wear analysis by Finlayson suggests that the axehead was never used. It may well have been a 'ritual' piece and in this respect, its inclusion in an essentially 'functional' assemblage of stone tools is interesting.

\section{CULTURAL AND CHRONOLOGICAL PARALLELS}

Although the flaked stone assemblage is of a generally undiagnostic type that was ubiquitous throughout prehistory there are a few pieces that are of more use as cultural and chronological indicators and these point to a Neolithic date for the assemblage. There are no Mesolithic indicators, and the production of fine regular flakes such as those from Kinbeachie is often cited as a Neolithic trend (Edmonds 1995), as is the use of faceted platforms. Edmonds cites serrated blades as a common element on many early Neolithic sites in England, though he finds them less widespread in Scotland (Edmonds 1995, 40). However, the collections of the National Museums of Scotland show that they do occur in Scotland, from Inverness and Morayshire to the Tweed Valley, though most seem to come from field collection rather than excavation. This may account 
for their apparent rarity among recent collections when the emphasis of lithic recovery in Scotland has shifted to excavation.

Leaf-shaped arrowheads are perhaps one of the best known Neolithic indicators, and the leaf point from Kinbeachie fits quite happily within this tradition. In general they are more common in the earlier Neolithic; Edmonds has pointed out that there is some regional variation in the different forms of leaf point (Edmonds 1995, 46) though the meaning of this is unclear.

The polished axehead is also of a type that may be cited as a general Neolithic indicator, particularly for the earlier Neolithic. Stone axes are relatively common in Scotland, though most occur as stray finds and the example from Kinbeachie is unusual in that it is well contexted from a pit, and associated with other structural evidence. The collections of the National Museums of Scotland have several small axes (eg NMS.X.AF91, from Urquhart in Morayshire), but even the smaller ones tend to be larger than the Kinbeachie example.

\section{INTERPRETATION OF THE SITE AT KINBEACHIE}

\section{S P Carter \& M M Dalland}

\section{DATE AND DURATION OF ACTIVITY}

All of the evidence from the 1997 excavation supports the Neolithic date for the site demonstrated by the radiocarbon dates: the diagnostic stone tools including a polished axe, the small assemblage of pottery and the remains of crop-plants. If the wider collections of worked stone and pottery from the surrounding fields are also included the picture remains remarkably coherent. Only the isolated find of Beaker pottery in a pit and one of Mr Fraser's three radiocarbon dates provides definite evidence for later activity. It is therefore reasonable to assume that all of the excavated features are from the same period of activity between 3500 and $2920 \mathrm{BC}$.

The actual duration of activity within this 600 year date range is not at all clear. Although the six radiocarbon determinations are not significantly different they were obtained from different samples and cannot be combined to produce a tighter date range. However, the stratigraphic simplicity of the site, accepting the loss of information from plough-truncation, does not support prolonged use and reconstruction on the site. Fifty-nine cut features were identified but only four of these (the pit group) had any stratigraphic relationships. The low but variable concentration of artefacts is also inconsistent with prolonged use when general levels of material on the site might be expected to rise and become more widely and evenly distributed. Similarly, the coherence of the small pottery assemblage is inconsistent with a prolonged deposition of pottery. It is suggested that the evidence is consistent with a site occupied for no more than a single generation.

The precise date of this short period of activity cannot be determined from the available evidence and none of the artefacts is closely dated independently from this site. The generally early Neolithic character of the worked stone has been noted above but this may be contrasted with the assumed late date for Neolithic Impressed Wares that is clearly challenged by the results from Kinbeachie (see Discussion below).

\section{NATURE AND FUNCTION OF THE SITE}

Interpretation is hampered by the severe plough truncation of the whole site, after which only the bases of deeper cuts survive. No contemporary surfaces have survived and any material deposited on the surface or in shallow cuts will have been incorporated into the ploughsoil where only 
robust materials like stone will survive for long periods. The low density of finds in the ploughsoil in this area recorded during field-walking suggests that the deposits lost through ploughing are similar to those that survived to be excavated.

This is a small site, covering roughly $750 \mathrm{sq} \mathrm{m}$. Two features have been recognized: a small rectangular timber structure and an intercutting group of pits. The significance of these features within the site is enhanced by the distribution of artefacts and carbonized grain recovered during excavation. They jointly contained 13 out of 17 pottery vessels identified (including all decorated sherds) and 10 of the 11 flint flakes. In addition, the pit group contained the small polished axehead and the rectangular structure was the location of the only concentration of carbonized cereal grain. All the other 44 excavated pits together contained only undecorated sherds of four pottery vessels, two flint flakes, variable concentrations of wood charcoal and hazel nut shell and a few cereal grains (also present in the rectangular structure and pit group).

These distribution patterns can be interpreted in terms of the dispersal of waste resulting from activities on site. From the carbonized plant remains there is evidence for a general dispersal of hearth ash (wood charcoal) containing food waste (nut shell). One specific incident resulting in the charring of a cleaned (possibly stored) barley crop occurred in or close to the site of the rectangular structure. More pottery and flint flakes were also deposited close to this structure. The simplest interpretation is perhaps that the site was a small farming settlement comprising one or more small rectangular timber buildings. Crops of barley and wheat were cultivated and wild foods such as hazel nuts and cherries were gathered. Cereal cultivation is also evidenced by the presence of the serrated flint blades which had probably been used to cut grasses/cereals. The acid soil will have destroyed any bone evidence for livestock and meat eating, but it is perhaps informative that only a small quantity of burnt bone fragments was recovered from one sediment sample.

Kinbeachie may be usefully compared with another excavated group of pits of Neolithic date at Grandtully in Perthshire (Simpson \& Coles 1990), where a group of 52 pits was identified in an area of about $350 \mathrm{sq}$ m. Excluding a well-defined group of seven Bronze Age cremation pits, the features were described as 'circular or sub-circular pits varying from $30 \mathrm{~cm}$ to $1.2 \mathrm{~m}$ in diameter. With one exception these were comparatively shallow, between 15 and $50 \mathrm{~cm}$ in depth' (Simpson \& Coles 1990, 33). Thirteen of these pits contained a small assemblage of Neolithic Impressed Wares representing parts of 14 vessels; two pieces of flint were also recovered. Two radiocarbon dates were obtained suggesting a date early in the second millennium $\mathrm{BC}$ for these features but this should be treated with caution as the radiocarbon determinations were made in the 1960s and it is likely that the error is understated. The excavators of Grandtully offered little comment on the likely function of the site, simply stating that 'the nature of the fill of these features would at first sight suggest domestic activity' (Simpson \& Coles 1990, 34-5). However, in the abstract to their paper they describe it as 'a late Neolithic phase with pottery deposited, perhaps ritually, in a number of pits'. There are clear parallels with Kinbeachie and the ritual association may be in doubt for Grandtully; this interpretation may owe more to the subsequent use of that site as a cremation cemetery rather than the nature of the Neolithic occupation.

\section{THE LOCAL NEOLITHIC CONTEXT}

The small settlement excavated at Kinbeachie did not exist in isolation and there is evidence that can be used to build up a picture of the contemporary landscape in the Black Isle. Neolithic artefacts were retrieved from the fields surrounding the site and these have already been included in the analysis of pottery and worked stone (above). A low density scatter of surface finds offers 
little scope for interpretation and in the case of the excavated site it is clear that the settlement was not highlighted by a concentrated artefact scatter. Two other Neolithic features have been identified in the Kinbeachie fields by Mr Fraser through radiocarbon dating of wood charcoal (Table 1). A pit in the 15 Acre Field, which returned a calibrated range of 3795-3640 BC, was investigated further in the 1997 evaluation and found to be a small isolated feature with no associated remains. The other dated Neolithic feature (3300-2890 BC), in the Five Acre Field, is contemporary with the excavated settlement and lies only $60 \mathrm{~m}$ to the north-east along the ridge. It is unfortunate that this field was not available for evaluation in 1997, leaving the context of this date uncertain. It at least serves to demonstrate the survival of features contemporary with the Neolithic settlement on the ridge and is possibly part of a loose cluster of contemporary activity/ settlement along the ridge crest.

Moving out from the immediate surroundings of the settlement to take in the whole of the Black Isle, two sources of evidence can be used to propose the nature and extent of Neolithic settlement. Thirteen Neolithic long cairns and chambered cairns of Orkney-Cromarty type have been identified in the Black Isle by field survey alone (Henshall \& Ritchie 2001, fig 11); none has been independently dated but they may be assumed to be broadly contemporary with the Kinbeachie settlement. All of the cairns are sited on the upper slopes of the central ridge that runs the length of the Black Isle (Fraser 1996). They are close to the upper limit of modern cultivation and overlook arable land. Recent fieldwalking in the Black Isle by Tim Phillips and his coworkers (Phillips et al 1999) has identified a low density scatter of Neolithic flaked stone throughout the lower ground, similar to that found in the Kinbeachie fields, with few artefacts recovered in the vicinity of the chambered cairns on the higher parts of the central ridge. This distribution appears to reflect a Neolithic landscape with widespread settlements and cultivated land up to about $100 \mathrm{~m}$ OD, overlooked by chambered cairns at 100 to $150 \mathrm{~m}$ OD.

This model would suggest that the settlement at Kinbeachie is only one of many settlements still to be identified. It is also apparent that these settlements are not readily detected by standard archaeological prospection techniques (field-walking, geophysical survey and aerial reconnaissance). The Kinbeachie site was only identified from a few sherds of pottery collected during repeated field-walking by the farmer immediately after ploughing. Neolithic pottery will not persist and accumulate in the ploughsoil to form a detectable artefact concentration; therefore unless an area is repeatedly walked the site will probably not be located. The results from Kinbeachie suggest that if these elusive Neolithic settlement sites are to be identified, much greater attention will have to be paid to isolated records of specifically Neolithic finds, especially pottery, as well as the major lithic scatters which can too easily dominate the results of fieldwalking projects. It is also important to note that if a site is regularly yielding pottery after ploughing it must be experiencing increasing plough truncation. The long-term preservation of shallow near-surface archaeological features is unlikely to be possible and the only course of action that can be recommended is prompt excavation.

\section{WIDER IMPLICATIONS OF THE SITE}

\section{SCOTTISH NEOLITHIC IMPRESSED WARES}

\section{A MacSween \\ Vessel form and decoration}

The pottery from Kinbeachie can be attributed to McInnes' 'Scottish Impressed Wares' (1969), also referred to as 'later Neolithic decorated wares' by Kinnes (1985). This type of pottery is 
generally accepted as a development of the early Neolithic carinated bowl tradition, and the northern equivalent of Peterborough Ware (Simpson \& Coles 1990, 38). Kinnes (1985, 22) noted that: 'The decorated styles of the later Neolithic lack real definition...', while McInnes commented that:

\begin{abstract}
The impressed wares of Scotland have a common denominator in their decoration and in their fabric, but the forms are innumerable and their decoration follows no classifiable pattern. . . On the sites at which [impressed wares are] found in any quantity it is the dominant form and decoration which varies, not the range of forms and decorative techniques which can be seen to be common throughout (McInnes 1969, 22-5).
\end{abstract}

This is illustrated in the example of the assemblage from Brackmont Mill, Fife, where, although there is a great deal of diversity in decorative techniques, rim forms and vessel forms, there was a clear preference for non-corded techniques — impressions arranged as rustication or simple horizontal or diagonal lines being most common (Longworth 1967, 73 fig 6).

A range of vessel forms is represented in Impressed Ware assemblages including bowls and taller vessels and the flat and broadened rims are often a focus for decoration by impression (Cowie 1993a, 122). Apart from the corrugated decoration on V1 (illus 6), most of the decorative techniques and schemes noted on the Kinbeachie pottery can be paralleled in other assemblages from various locations in the Scottish mainland. Finely incised lines made with a thin tool with a sharp point have been noted, for example, on the exterior of a vessel with a slightly flattened rim from Hedderwick, East Lothian (Callander 1929, fig 3, no 7) and on a fragmentary T-shaped rim from Kinloch Farm, Collessie, Fife which has possible oblique incised lines on the exterior (Cowie 1982, fig 4.5). At Balfarg, Fife incised lines were noted on the external surfaces of a number of sherds, mostly fragmentary, but including a very worn T-headed rim in a hard, compact fabric, with transverse incisions on the flat top of the rim (1993a, illus 42, P84) which can be compared with V3 (illus 7) from Kinbeachie. The shorter, shallower, grooved decoration seen on V2, V5 and V10 (illus 7) at Kinbeachie can also be paralleled elsewhere including the assemblage from Torrs Warren, Luce Sands, Galloway (cf Cowie 1996, 49 fig 23.259).

A stamped design similar to that on V6 (illus 7) at Kinbeachie was noted on a vessel from Hedderwick (Callander 1929, fig 55 4-7, especially no 7). This decoration can also be compared with pottery from Torrs Warren which Cowie (1996, 46, eg 47 fig 21.219) describes as being decorated with 'jab-and-drag' impressions. The bone rustication on the sherd from the field collections (1091:42) can be compared with similar rustication in the same assemblage (Cowie 1996, fig 23.258). Fingernail impressions, represented on sherd 1091:42 from Kinbeachie, are included in many assemblages, sometimes dragged fingernail impressions extending all over the exterior of the vessel as at Old Kilpatrick, Dumbartonshire (Callander 1929, 60 fig 41, 61 fig 42.1). Closer parallels can be found in the vertical impressions arranged in horizontal rows for example at Torrs Warren (ibid, fig 23, no 257) and at Hedderwick (Callander 1929, fig 51.1 \& 2). Cordons, as on V6 (illus 7) from Kinbeachie, while not common, occur occasionally in other assemblages. In the assemblage from Brackmont Mill, Fife, for example, a cordon separates the decorated from the undecorated portion of the vessel (Longworth 1967, 68 fig 4.3).

The parallels drawn here show the use of similar forms of impressed decoration over much of the country but with considerable variation between individual assemblages. Thirty years after McInnes' article (McInnes 1969), strong regional groups have still not been identified although some indications of regional patterning can be suggested. The use of impressions to produce 
heavy rustication, for example, may have a west coast bias being the most common form of decoration at sites such as Luce Sands, Galloway (McInnes 1964, 50).

The probability of a north-eastern Scottish regional style of Impressed Wares, including biconical forms, evolving out of earlier Neolithic pottery in the area (as summarized by Henshall (1983) ) has been suggested by Cowie (1993b, 17-18) and Sheridan (1997, 221). Cowie (1993b, 18) noted that:

the presence of a vigorous Earlier Neolithic decorated pottery style in the north-east, characterized by biconical vessels with incised and stab-and-drag decoration, suggests that there may be a satisfactory 'indigenous' context for the presence in that area. . for the range of decorated Late Neolithic biconical vessels with impressed decoration, best represented by the pit group from Brackmont Mill (McInnes 1969, 25; Longworth 1967, 67-75).

This link was further strengthened by the recent discovery of sherds of classic Unstan bowl form at Spurryhillock near Stonehaven, Kincardineshire (Cowie 1997). Certainly, the upper portion of V1 from Kinbeachie (illus 6) has affinities with Unstan bowls in the position and the restricted nature of the decoration. So too do the shallow bowl with sharply developed collar and internally bevelled rim, from Grandtully (Simpson \& Coles 1990, 39 illus 8.P1), and the collared vessel from Knapperty Hillock, Old Deer, Aberdeenshire (Henshall 1983, 26, fig 5.7). In fact it is not out of the question to see some of the southern Scottish forms of impressed wares as a development from vessels of the style of V1 at Kinbeachie. The Meldon Bridge style of vessel (Speak \& Burgess 1999) for example, could be produced by shortening the collar and broadening the rim bevel.

\section{Date}

Prior to the dating of Kinbeachie there were very few radiocarbon dates for features associated with Impressed Wares in Scotland (those presented here are as calibrated in Sheridan 1997, 220-1). Dates for material associated with the pottery from Grandtully, Perthshire, Gak-1398 and Gak-1396 (Simpson \& Coles 1990, 35), are now considered too unreliable to be quotable. Dates for the Meldon Bridge (Peeblesshire) assemblage range from 3350-2550 cal BC (SRR 646) to 2900-2300 cal BC (SRR 645) (Speak \& Burgess 1999, 102-4), suggested a date range in the third millennium $\mathrm{BC}$. While an early to mid third millennium date was tentatively accepted for this type of pottery (the 'Late Neolithic Impressed Wares' of Kinnes 1985), Sheridan (1997) pointed out that the possibility of dates in the mid to late fourth millennium should not be discounted. Two dates for the Meldon Bridge material in the fourth millennium (4100-2700 cal BC: SRR 643 \& 3750-3000 cal BC: SRR 644) were dismissed as unreliable by the excavator, but a date of 3500-3440/3380-3070 cal BC (Beta-73951) has since been obtained for pottery from Blairhall Burn, Dumfriesshire (Strachan et al 1998, illus 15). More recently in Arran, a pit containing Impressed Ware has been dated to 3354-2918 cal BC (GU-9441) (GUARD 731, Arran Ring Main Water Pipeline, Beverley Ballin-Smith, pers comm). With the Kinbeachie pottery securely dated to the range $3500-2920 \mathrm{cal} \mathrm{BC}$, a date in the mid to late fourth millennium $\mathrm{BC}$ for at least some of the Scottish Impressed Wares can be demonstrated. Therefore the earliest Scottish Impressed Wares are contemporary with 'Unstan Bowls' (Kinnes 1985, illus 4) and with the earlier part of the date range for Peterborough Ware (Gibson 1995, 30; Gibson \& Kinnes 1997). 


\section{Context}

As Cowie (1993a) and Kinnes (1985) have noted, many finds of Impressed Wares have been recovered from unstratified collections from coastal and dune sites such as Hedderwick, Luce Sands and Tentsmuir (Longworth 1967). Even when recovered during excavation it can often not be directly related to features. At Balfarg, the pottery, although confined to a very limited area of the site, was worn and fragmentary and was thought to represent domestic rubbish spread as part of manuring of the old land surface beneath the ring cairn (Cowie 1993a, 122). Again at Biggar Common, Lanarkshire, Sheridan (1997) noted that the pottery was found at widely scattered find-spots and that none of it was directly associated with other finds or features. The assemblage from North Mains, Strathallan, Perthshire was from near the margin of the round barrow, but the context was ambiguous (Barclay 1983, 192). In other cases the assemblage is too small for any discussion apart from recording its presence, as with that from the ditched enclosure at Kinloch Farm, Fife (Cowie 1982) or the handful of sherds from the 'multiperiod structure' at Mid Gleniron Farm, Glenluce, Wigtownshire (Corcoran 1969, 66).

Excavated assemblages that do have a definite context are from the pit groups of Brackmont Mill (Longworth 1967, 72), Grandtully (Simpson \& Coles 1990), Meldon Bridge (Speak \& Burgess 1999) and Wellbrae, Lanarkshire (Cowie, forthcoming) to which can now be added Kinbeachie. The assemblage from Brackmont Mill was recovered from a pit containing an even density of sherds intermingled with stones and sand including burnt material, and nine fragments of flint. Fifty-one sherds of pottery were recovered from the pit, representing at least 20 vessels. The sherds had fresh fractures and little abrasion. No vessel was represented by more than eight sherds, which, added to the high ratio of rims to other sherds, pointed to selection of material for deposition in the pit. At Meldon Bridge (Speak \& Burgess 1999) a number of shallow pits were found to have Impressed Wares. Two of these pits preserved evidence for a lining of crushed pottery and it may be concluded, as at Brackmont Mill, that this reflects 'structured deposition' rather than casual loss or disposal of refuse.

There is no such evidence from the other sites with pits. At Grandtully, Perthshire (Simpson $\&$ Coles 1990) the pottery was recovered from a number of shallow pits and scoops. Some of the hollows appeared to have been back-filled at the same time because sherds of three vessels were found in two or three pits. The context of the pottery from Kinbeachie parallels this earlier discovery.

The almost total absence of Impressed Wares from funerary contexts is striking; to date the only record is for a few sherds from the secondary use of the chamber and the base of the forecourt blocking at Cairnholy I (Piggott \& Powell 1949, 120). It does not follow from this that Impressed Wares do not occur in ritual contexts as the pits at Brackmont Mill and Meldon Bridge demonstrate. However, the regular association of this type of pottery with possible settlement sites, unremarkable pit groups and other insignificant, possibly ephemeral, contexts suggests that finds of Impressed Wares are signalling the location of Neolithic settlements. Kinbeachie may simply be a relatively coherent and well-explored example of a widespread site type.

\section{THE USE OF FLINT}

\section{Wickham-Jones}

The flint assemblage from Kinbeachie is interesting for several reasons. Like most assemblages it includes many very general pieces, but those with cultural or chronological parallels all point to a 
Neolithic date, probably towards the earlier part of the Neolithic. This is confirmed by other elements of the site, notably the pottery and the radiocarbon determinations.

The knappers clearly had access to good quality flint and were skilful in producing regular flakes and formal tools for use. On occasion they supplemented their flint with other local stones such as quartz and quartzite, adapting their technique to produce similar tools. There is a general lack of debitage in the assemblage: there are no cores, and little manufacturing waste, despite the use of sieving to recover material from the excavated areas. In general the collection would seem to have resulted from the use of tools rather than their manufacture. Moreover, the very small size of the assemblage, given the area over which it has been collected, might argue that even the deposition of used tools has not been simple. This is particularly so for the main excavated area where evidence for a rectangular structure and associated features was found.

Few early Neolithic structures have been excavated in Scotland, and those that have, have produced few lithic artefacts (Wickham-Jones \& Mackenzie 1996). This is perhaps not surprising given that people are unlikely to manufacture tools in a darkened house interior, or leave piles of sharp flint waste in close vicinity to their main dwelling areas. This is in great contrast to preceding Mesolithic habits, where structural remains appear to coincide with large quantities of lithic waste (eg Wickham-Jones 1990), but it is paralleled subsequently in the Bronze Age where house remains tend to produce few artefacts (eg Wickham-Jones in Stevenson 1984). The structure at Kinbeachie was directly associated with only five flakes, all found in two post-holes at one corner. Although there were six pieces from features close by, and a further three pieces from the ploughsoil in the trench, this hardly represents a great quantity of flint use. In part this must be a timely reminder of the overblown importance that is attached to flint tools today. It is generally assumed that they were of great importance in the past, because they are one of the few elements of the material culture to have survived, whereas it is quite likely that the general needs of a household could be served by relatively few stone tools, together with a sophisticated repertoire of tools of other materials. It is also likely that a refined pattern of tool discard was in operation so that rubbish was disposed of away from the dwelling structures.

Use-wear analysis on a few of the pieces, including most of the retouched tools, produced evidence for a variety of tasks from cutting grasses or cereals to shaving wood and working on softer materials. With the exception of the serrated blades, there was no evidence that the morphological tool types recognized today, such as edge retouched pieces, were all used in the same way in the past. This would seem to confirm the idea of the assemblage as a working collection of tools suited to a variety of purposes.

\section{KINBEACHIE AND NEOLITHIC SETTLEMENT}

\section{G J Barclay}

The nature of Neolithic settlement has been the subject of much debate in recent years. It is not intended to go over the arguments again in detail here, but in short there have been two views. First, that the form of settlement of the earlier and perhaps even the later Neolithic throughout the British Isles was not the settled farm traditionally envisaged, and that the population may have been largely mobile, operating an economy based on the herding of cattle within a territory (Barrett 1994; Thomas 1996; Parker Pearson 1993; Edmonds 1995). Some places (eg causewayed enclosures) may have operated as gathering places for these mobile communities. The alternative view is that the mobile Neolithic hypothesis has not been proved, and may rely too heavily on a supposed lack of a certain sort of evidence (eg the remains of domestic buildings) (Barclay 1997). 
Further, while the model is perhaps valid for the parts of southern Britain where it was developed, it is based on a regionally restricted data set and evidence from other parts of Britain and Ireland may indicate a greater diversity including a settled agriculture based on cereal cultivation. Unfortunately the 'mobile Neolithic' hypothesis has shown tendencies to become an unquestioned orthodoxy, but it has recently attracted some criticism (Cooney 1997; Barclay 2000).

In Scotland knowledge of Neolithic settlement is to a great extent also regionally restricted - the majority of excavation has taken place in the west and north (Barclay 1997, 3; Barclay 2000) leaving the few known sites in the eastern lowlands as isolated and apparently unrelated spots on distribution maps. It has been argued (Barclay 1997) that the dearth of evidence of settlement for much of Scotland is due to the lack of fieldwork, rather than to any lack of original human settlement: the eastern lowlands are densely scattered with ceremonial and burial sites of the Neolithic and with artefacts such as leaf-shaped arrowheads and polished stone axes. In addition there are many scatters of flint and other stone, and more rarely pottery, which may represent settlement sites, but a bare handful has been investigated. In that context, the discovery and excavation of the features at Kinbeachie is a welcome addition to knowledge.

The Kinbeachie site has clearly suffered truncation by ploughing and soil erosion, and it is certain that the remaining features are only a proportion of those originally on the site. We are left with a generally chaotic collection of pits and post-holes, the only coherent pattern being the group interpreted by the excavators as a possible house. Two questions fall to be considered: is the site domestic? and could the building be a house? First, the categorization of a site as 'domestic' is in some ways meaningless; 'ritual' in its broadest sense structures the actions of everyday life. However, it is recognized that some sites and areas are set aside for more formal ritual activity, involving the creation of special structures or the marking of special places, and others are the focus of everyday life. One commonly identified feature of earlier Neolithic sites has been collections of pits containing charcoal, hazelnuts and most especially pottery. For many years they were interpreted as 'rubbish pits' or 'grain storage pits', permitting the labelling of sites on which they were found as 'domestic' (Case 1969). However, the oddity of their fills, their small numbers in relation to any likely need for the disposal of 'rubbish', and their occurrence, particularly in Scotland, mainly on sites with a contemporary or later monumental, formal ceremonial function, has suggested more complex explanations. The idea of 'structured deposition' was developed to explain these odd pits (Richards \& Thomas 1984), perhaps the consequence of the disposal of 'ritually charged' material (Richards 1993); that is, material whose use in ceremonial activity possibly results in it being seen as dangerous in some way. For example, at the group of ceremonial and burial sites at Balfarg/Balbirnie in Fife the earliest features, on a site that later saw the construction of mortuary structures, two henges, cairns and stone circles, were two groups of pits containing earlier Neolithic pottery. One of the most striking features was the sealing of some pits with a layer of cobbles (Barclay \& Russell-White 1993).

While some of the features at Kinbeachie could fall into the rather wide definition of 'structured deposition' - particularly F48, which contained a small polished stone axehead the very small quantities of pottery from the relevant features would argue against this interpretation. We are certainly in danger of moving from labelling all 'pits' (some of which may be post-holes) as 'domestic' to interpreting all of them as involving 'structured deposition'. There is a distinction to be drawn between the chance inclusion of pot sherds in the fill of a pit or posthole and the careful placing of substantial quantities of pottery in a particular way in a specially sealed pit. However, we must be careful again about the labelling of sites as 'practical', 'domestic' or 'secular' in contrast to 'esoteric', 'ceremonial' or 'religious'. 
Turning to the structure, the pattern of post-holes, if they form a single unit, can be interpreted in a number of ways. First, as a simple setting of timbers or, if linked, a rectilinear enclosure. If part of a roofed building, the posts could form both wall and support for a roof. Alternatively, the post setting could be the aisle posts of a larger structure, the outer walls of which have left no archaeological trace on this heavily-truncated site. We are fortunate in having up-to-date summaries of the British and Irish evidence for Neolithic buildings (Barclay 1996; Darvill 1996; Grogan 1996). The closest comparable post-setting is that at Raigmore, Inverness, some $20 \mathrm{~km}$ away (Simpson 1996). Here there were not only pits containing 'occupation debris' but also the remains of a roughly rectangular setting of posts, with a roughly central hearth. It has been suggested that the post-holes that survive represent the remains of two phases of building. Once again the posts could have formed the wall of a building, the aisle posts of a larger building, or even an open fenced enclosure. The overall dimensions of the setting were 14 by $6 \mathrm{~m}$, of the likely individual phases, c 10 by $5 \mathrm{~m}$. The material associated with it would not be out of place on a domestic site (Jones quoted in Bradley 2000). The pre-cairn activity is associated with calibrated radiocarbon dates of 4000-3650 cal BC and 2900-2500 cal BC (Simpson 1996). As Bradley puts it 'The house of the living was monumentalized by a stone cairn dedicated to the dead' (Bradley 2000). We would certainly be unwise to label the structure as 'ritual' merely because it subsequently had a cairn built over it.

The north-east of Scotland provides some parallels for the scatter of post-holes at Kinbeachie. The evidence from Raigmore and Kinbeachie may be contrasted with the major structure at Balbridie in Aberdeenshire (Fairweather \& Ralston 1993). The Balbridie structure is on a completely different scale, measuring 24 by $10 \mathrm{~m}$, and comprising more massive structural elements, for example the setting of posts in large bedding slots. The significant differences between Balbridie and the other sites raises issues of function, permanence and chronology that should be addressed once Balbridie is published in full. It can be argued that Balbridie has not been fully integrated into explanations of the Neolithic because of its apparent uniqueness. However, a very similar structure has now been excavated at Claish Farm, near Callander (Barclay et al 2002).

If the timber structures beneath the Raigmore cairn are taken to have had a ceremonial or funerary function, and that the Kinbeachie structure is analogous, then lowland Scotland can provide very broad parallels for unroofed structures, but once again on a larger scale. At Balfarg, two round-ended timber enclosures, the more complete measuring 18 by $9 \mathrm{~m}$, surrounded a chaotic pattern of posts, perhaps representing exposure platforms; one was radiocarbon dated to around 3030-2880 cal BC. One of the enclosures was covered by a mound, containing Grooved Ware; through the mound a single axial post was visible (Barclay \& Russell-White 1993). At Littleour a similar round-ended enclosure, measuring 22 by $7 \mathrm{~m}$ had been erected in the early to mid third millennium, a large axial post-hole lying in its eastern half. Several hundred years later a pit was dug in which Grooved Ware and fine unused flint tools were deposited. It has been argued (Barclay \& Russell-White 1993; Barclay \& Maxwell 1998) that the Balfarg and Littleour structures were not roofed, nor had a domestic function. It is interesting to note that the Littleour and Claish structures, which have radically different internal arrangements, are the same shape and size - indeed the plan of the boundary of one can be laid over the other.

In conclusion, the balance of probability seems to suggest that the Kinbeachie structure is part of a single period inhabited site, but a site that saw 'ritual' elements, as any place associated with human use must see some ordering of life's activities. The post structure may well be interpretable as a roofed 'house', and there are broad parallels for slightly-built rectilinear buildings from many parts of Britain and Ireland (Darvill 1996; Grogan 1996). Analysis of 
Neolithic pit and post-hole complexes in lowland Scotland (Barclay 2002) reveals a marked tendency towards what might be described as ' rectilinear incoherence', which is fair description of the structure at Kinbeachie.

\section{ACKNOWLEDGEMENTS}

The excavations at Kinbeachie and the subsequent analysis and publication of the results were commissioned and funded by Historic Scotland. The project was initiated by Deirdre Cameron for Historic Scotland and the later stages of the analysis were managed by Dr Noel Fojut. We wish to thank Andrew Fraser of Kinbeachie for permission to undertake the fieldwork and for sharing his enthusiasm for the archaeology of the area. Jonathan Wordsworth provided guidance over the pre-1997 investigations and also assisted with the 1997 excavations which were supervised by Magnar Dalland. Finds from the earlier excavations and fieldwalking are deposited in Inverness Museum \& Art Gallery and we thank Patricia Weeks (Assistant Curator, Archaeology) for the loan of this material. Tim Phillips (University of Reading) is thanked for discussing his fieldwalking project and for providing the results in advance of their publication.

Caroline Wickham-Jones wishes to thank Tam Ward, then of the National Museums of Scotland, who was very helpful in locating parallels for the axehead and the serrated flakes and Diane Dixon who identified the rock type of the axehead. Dr Mark Edmonds, Jill Harden, Ian Shepherd and Dr Graeme Warren have all advised over particular aspects of her work. Dr MacSween would like to thank Dr Alison Sheridan and Trevor Cowie, both of the National Museums of Scotland, for helpful discussions on the pottery assemblage.

The illustrations for this paper were prepared by Laura Speed (illus $1-5$ \& 8 ) and Sylvia Stevenson (illus 6, 7,9\&10).

\section{REFERENCES}

Barclay, G J 1983 'Sites of the third millennium bc to the first millennium ad at North Mains, Strathallan, Perthshire', Proc Soc Antiq Scot, 113 (1983), 122-281.

Barclay, G J 1996 'Neolithic buildings in Scotland', in Darvill, T, \& Thomas, J (eds), 61-75.

Barclay, G J 1997 'The Neolithic', in Edwards, K \& Ralston, I B M (eds) Scotland: Environment and Archaeology, 8000 BC to AD 1000, 127-49. Chichester.

Barclay, G J 2000 'Between Orkney and Wessex: the search for the regional Neolithics of Britain', in Ritchie, A (ed), Neolithic Orkney in its European Context, 275-85. Cambridge.

Barclay, G J 2002 'Neolithic settlement in the lowlands of Scotland: a preliminary survey', in Armit, I, Murphy, E, Nelis, E \& Simpson, D D A (eds) Neolithic Settlement in Ireland and Western Britain. Belfast.

Barclay, G J, Brophy, K \& MacGregor, G 2002 'A Neolithic building at Claish Farm, near Callander, Stirling Council, Scotland, UK', Antiquity, 76 (2002), 13-14.

Barclay, G J \& Maxwell, G S 1998 The Cleaven Dyke and Littleour: monuments in the Neolithic of Tayside. Edinburgh (= Soc Antiq Scot Monogr, 13).

Barclay, G J \& Russell-White, C J 1993 'Excavations in the ceremonial complex of the fourth to second millennium BC at Balfarg/Balbirnie, Glenrothes, Fife', Proc Soc Antiq Scot, 123 (1993), 43-210.

Barrett, J C 1994 Fragments from Antiquity. Oxford.

Bradley, R 2000 The Good Stones. Edinburgh (=Soc Antiq Scot Monogr, 17).

Callander, J G 1929 'Scottish Neolithic Pottery', Proc Soc Antiq Scot, 63 (1928-9), 29-98.

Case, H 1969 'Neolithic explanations', Antiquity, 43 (1969), 176-86.

Cooney, G 1997 'Images of settlement and the landscape in the Neolithic', in Topping, P (ed) Neolithic Landscapes, 23-31. Oxford. 
Corcoran, J X W P 1969 'Excavation of two chambered cairns at Mid Gleniron Farm, Glenluce, Wigtownshire', Trans Dumfriesshire Galloway Natur Hist Antiq Soc, 46 (1969), 29-90.

Cowie, T 1982 'The pottery', in Barber, J W'The investigation of some plough truncated features at Kinloch Farm, Collessie in Fife', Proc Soc Antiq Scot, 112 (1982), 527-9.

Cowie, T 1993a 'Later Neolithic Impressed Wares', in Barclay, G J \& Russell-White, C J, 121-6.

Cowie, T 1993b 'A survey of the Neolithic pottery of eastern and central Scotland', Proc Soc Antiq Scot, 123 (1993), 13-41.

Cowie, T 1996 'Torrs Warren, Luce Sands, Galloway: a report on archaeological and palaeoecological investigations undertaken in 1977 and 1979', Trans Dumfriesshire Galloway Natur Hist Antiq Soc, 71 (1996), 11-105.

Cowie, T 1997 'The Neolithic pottery sherds', in Alexander, D 'Excavation of pits containing decorated Neolithic pottery and early lithic material of possible Mesolithic date at Spurryhillock, Stonehaven, Aberdeenshire', Proc Soc Antiq Scot, 127 (1997), 22-4.

Cowie, T forthcoming 'The pottery', in Alexander, D 'Report on excavations at Wellbrae'.

Darvill, T 1996 'Neolithic buildings in England, Wales and the Isle of Man', in Darvill, T \& Thomas, J (eds) 77-111.

Darvill, T \& Thomas, J (eds) 1996 Neolithic Houses in Northwest Europe and Beyond, Oxford.

Edmonds, M 1995 Stone Tools and Society. London.

Fairweather, A D \& Ralston, I B M 1993 'The Neolithic timber hall at Balbridie, Grampian Region, Scotland: the building, the date, the plant macrofossils', Antiquity, 67 (1993), 313-23.

Fraser, S 1996 Physical, Social and Intellectual Landscapes in the Neolithic: contextualising Scottish and Irish Megalithic architecture. Unpublished $\mathrm{PhD}$ thesis presented to the University of Glasgow.

Gibson, A 1995 'First impressions: a review of Peterborough Ware in Wales', in Kinnes, I \& Varndell, G (eds) 'Unbaked Urns of Rudely Shape', 23-39. Oxford.

Gibson, A \& Kinnes, I 1997 'On the urns of a dilemma: radiocarbon and the Peterborough problem', Oxford J Archaeol, 16 (1997), 65-72.

Green, H S 1980 The Flint Arrowheads of the British Isles, 2 vols. Oxford (=Brit Archaeol Rep Brit Ser, 75).

Grogan, E 1996 'Neolithic houses in Ireland', in Darvill, T \& Thomas, J (eds), 41-60.

Henshall, A S 1983 'The Neolithic pottery from Easterton of Roseisle, Moray', in O'Connor, A \& Clarke, D V (eds) From the Stone Age to the Forty-Five. Studies presented to R B K Stevenson, 19-44. Edinburgh.

Henshall, A S \& Ritchie J N G 2001 The Chambered Cairns of the Central Highlands. Edinburgh.

Holden, T G 1998 'Charred Plant Remains', in McCullagh, R P J \& Tipping R (eds) The Lairg Project 1988-1996: The evolution of an archaeological landscape in Northern Scotland, 165-72. Edinburgh.

Kinnes, I A 1985 'Circumstance not context: the Neolithic of Scotland as seen from outside', Proc Soc Antiq Scot, 115 (1985), 15-57.

Longworth, I H 1967 'Further discoveries at Brackmont Mill, Brackmont Farm and Tentsmuir, Fife', Proc Soc Antiq Scot, 49 (1967), 60-92.

McInnes, I J 1964 'The Neolithic and Early Bronze Age pottery from Luce Sands, Wigtownshire', Proc Soc Antiq Scot, 97 (1964), 40-81.

McInnes, I J 1969 ‘A Scottish Neolithic pottery sequence', Scott Archaeol Forum, 1 (1969), 19-30.

Maclean, A C \& Rowley-Conway, P A 1984 'The carbonized material from Boghead, Fochabers', in Burl, H A W 'Report on the Excavation of a Neolithic mound at Boghead, Speymouth Forest, Fochabers, Moray 1972 and 1974', Proc Soc Antiq Scot, 114 (1984), 35-73.

Phillips, T, Jack, A \& Seright, S 1999 The Black Isle Fieldwalking Project. Unpublished report, University of Reading, Dept of Archaeology.

Piggott, S \& Powell, T G E 1949 'The excavation of three Neolithic chambered tombs in Galloway, 1949', Proc Soc Antiq Scot, 88 (1949), 103-61.

Richards, C 1993 'Contextual analysis of the Grooved Ware at Balfarg' in Barclay, G J \& Russell-White, C J, 185-192.

Richards, C forthcoming Dwelling among the Monuments, excavations at Barnhouse and Maeshowe, Orkney. 
Richards, C \& Thomas, J 1984 'Ritual activity and structured deposition in later Neolithic Wessex', in Bradley, R \& Gardiner, J (eds), Neolithic Studies: a review of some current research. Oxford (= Brit Archaeol Rep Brit Ser, 133).

Sheridan, A 1997 'Pottery', in Johnston, D A 'Biggar Common 1987-93: an early prehistoric funerary and domestic landscape in Clydesdale, South Lanarkshire', Proc Soc Antiq Scot, 127 (1997), 202-3.

Simpson, D D A 1996 'Excavation of a kerbed funerary monument at Stonyfield, Raigmore, Inverness, Highland, 1972-3', Proc Soc Antiq Scot, 126 (1996), 53-86.

Simpson, D D A \& Coles, J M 1990 'Excavations at Grandtully, Perthshire', Proc Soc Antiq Scot, 120 (1990), 33-44.

Speak, S \& Burgess, C 1999 'Meldon Bridge: a centre of the third millennium BC in Peeblesshire', Proc Soc Antiq Scot, 129 (1999), 1-118.

Strachan, R, Ralston, I \& Finlayson, B 1998 'Neolithic and later prehistoric structures, and early medieval metal-working at Blairhall Burn, Amisfield, Dumfriesshire', Proc Soc Antiq Scot, 128 (1998), 55-94.

Stevenson, J B 1984 The Excavation of a Hut Circle at Cul a'Bhaile, Jura; Proc Soc Antiq Scot, 114 (1984), $126-60$.

Thomas, J 1996 'Neolithic houses in mainland Britain and Ireland — a sceptical view', in Darvill, T \& Thomas, J (eds) 1-12.

Wickham-Jones, C R 1990 Rhum: mesolithic and later sites at Kinloch, excavations 1984-86. Edinburgh (= Soc Antiq Scot Monogr, 7).

Wickham-Jones, C R \& Mackenzie, J R 1996 ‘An unusual lithic assemblage from Lunanhead, Angus', Proc Soc Antiq Scot, 126 (1996), 1-16.

Wordsworth, J 1997 Kinbeachie Farm, Culbokie, Black Isle: An Assessment of current archaeological discoveries and a Project Design for future work. Unpublished report for Historic Scotland.

This report is published with the aid of a grant from Historic Scotland 